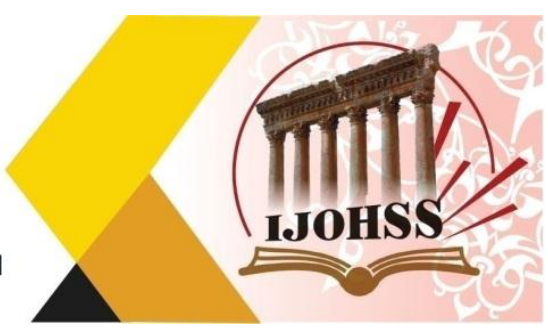

\title{
الاكثور رفيق يونس المصري وجهوده في التفسير
}

\author{
أ.م.د. أبو القتوح عبد القادر شاكر

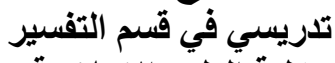

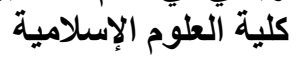 \\ الجامعة العراقية الإسلة العزية \\ العراق
}

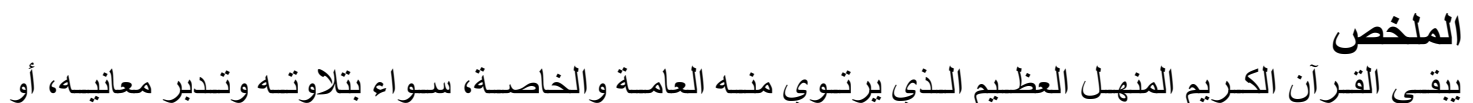

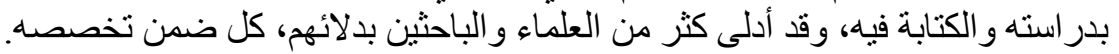

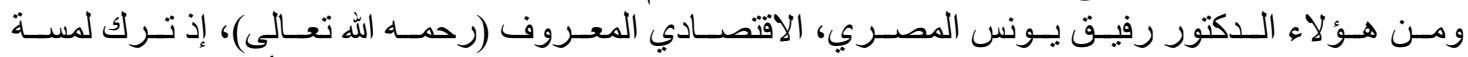

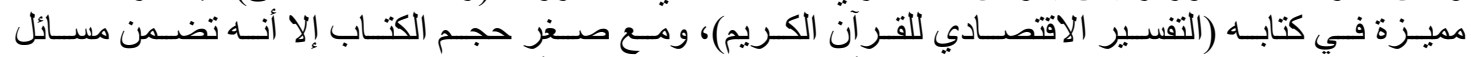

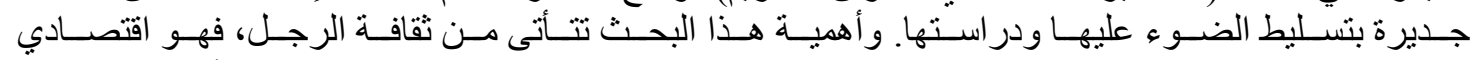

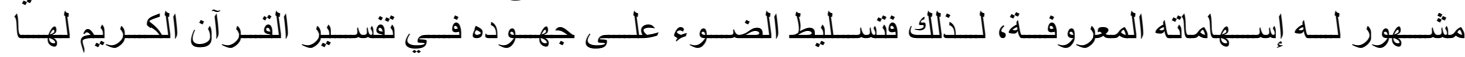

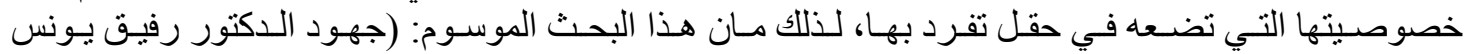
المصري في كتابه التفسير الاقتصادي للقر آن آن الكريم).

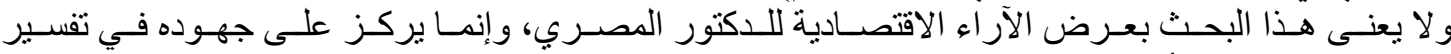

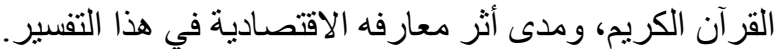

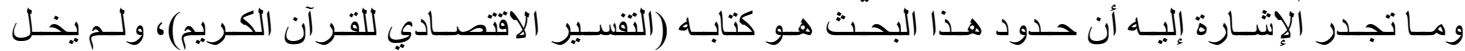

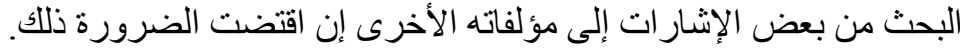

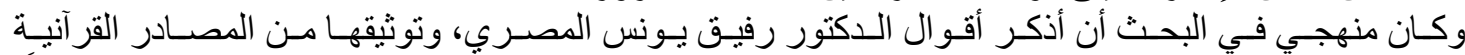

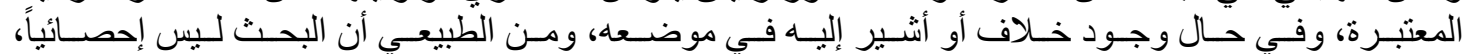
و وإنما جرى انتقاء بعض الثرال الثو اهد في مسائل مختلفة لدر استها.

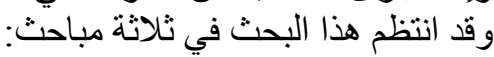

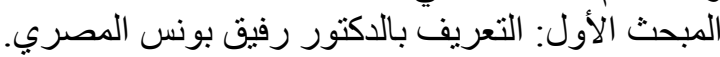

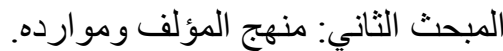
المبحث الثالث: جهوده التفسيرية. الخاتمة التي بينت فيها أهم النتائج و التوصية. ثم قائمة المصادر و المر اجع. الكلمات المفتاحية: الدكتور رفيق يونس المصري، تفسير القرآن. 


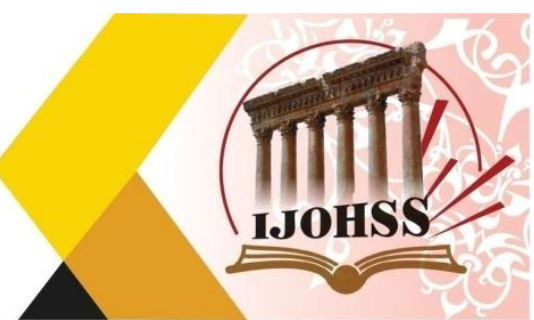

\title{
Dr. Rafiq Younis Al-Masry and his Efforts in Interpretation
}

\author{
Assist. Prof. Dr. Aboul Fotouh Abdel Qader Shaker \\ Lecturer in the Department of Interpretation \\ College of Islamic Sciences \\ Iraqi University \\ Iraq
}

\begin{abstract}
The holy Qur'an remains the great source from which the public and the private are satiated.

Among them is Dr. Rafiq Younis Al-Masry, the well-known economist (may God have mercy on him), who left a distinctive touch in his book (The Economic Interpretation of the Holy Qur'an), and despite the small size of the book, it included issues worthy of highlighting and studying.

The importance of this research stems from the man's culture, as he is a famous economist with his well-known contributions. Therefore, highlighting his efforts in the interpretation of the Noble Qur'an has its own peculiarity that places him in a field that is unique in it. Therefore, this research marked: Generous.

This research is not meant to present the economic views of Dr. Al-Masry, but rather focuses on his efforts in interpreting the Holy Qur'an, and the extent of the impact of his economic knowledge on this interpretation.
\end{abstract}

Keywords: Dr. Rafiq Younis Al-Masry, interpretation of the Qur'an. 


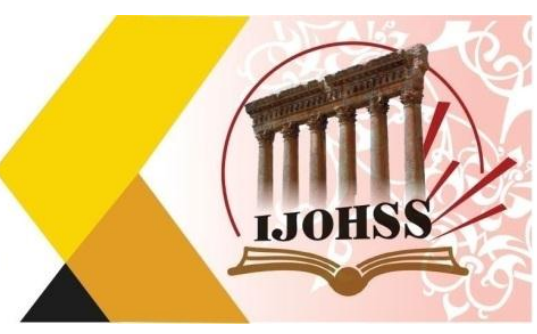

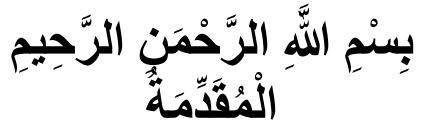

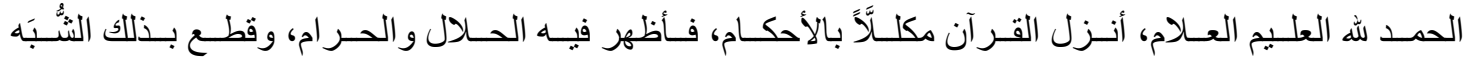

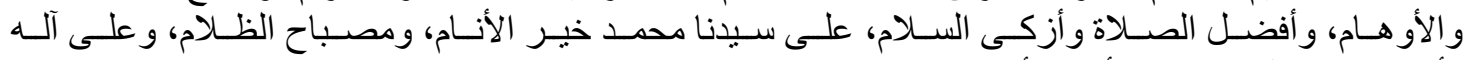
وأصحابه وحملة شريعته الأئمة الأعلام.

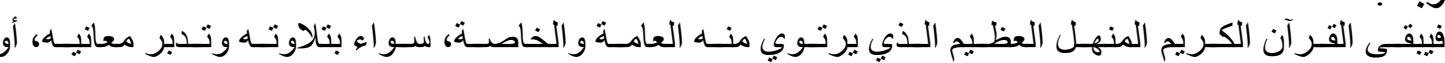

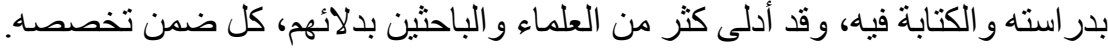

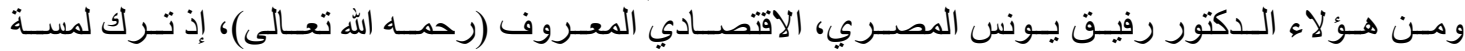

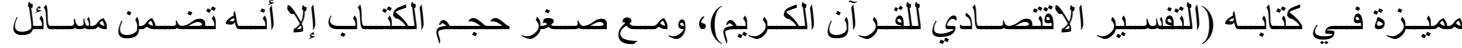
جديرة بتسليط الضوء علئه عليها ودر استها.

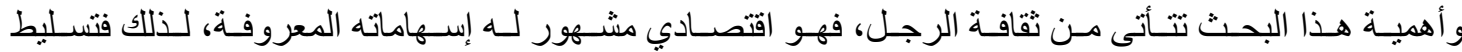

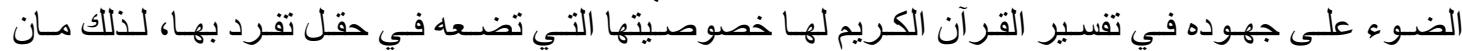

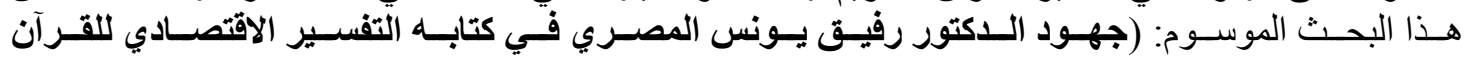

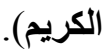

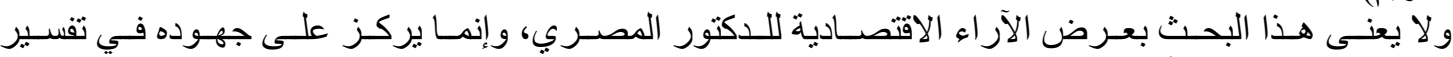

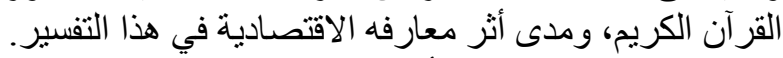

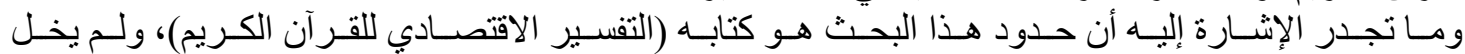

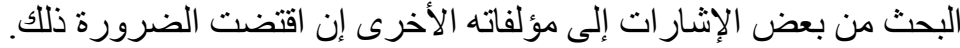

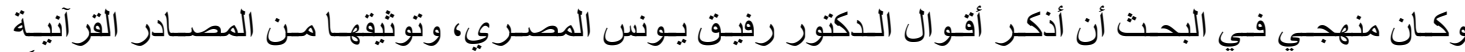

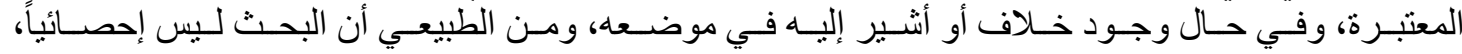

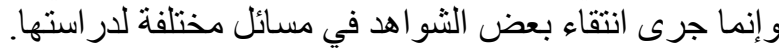
وقد انتظم هذا البحث في ثلاثثة مباحث:

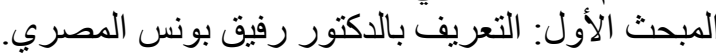

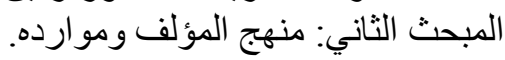

المبحث الثالث: جهوده التفسيرية. الخاتمة التي بينت فيها أهم النتائج و التوصئ. التوصيات.

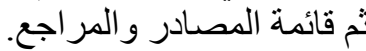

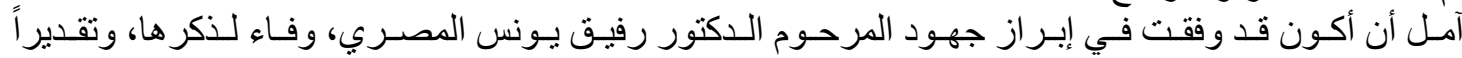
وصلى الله على سيدنا محمد و على آله وصحبه. لجهوده، والله الهادي إلى سواء السبيل.

\section{المبحث الأول}

\section{التعريف بالاكتور رفيق بونس المصري}

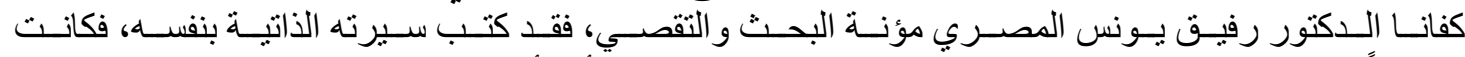

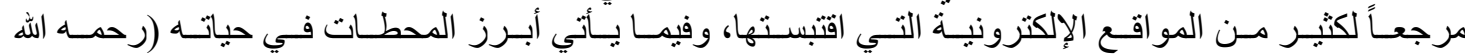




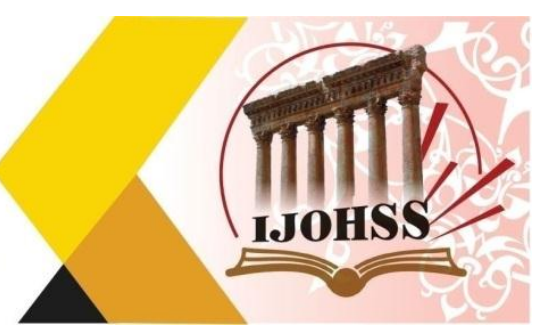

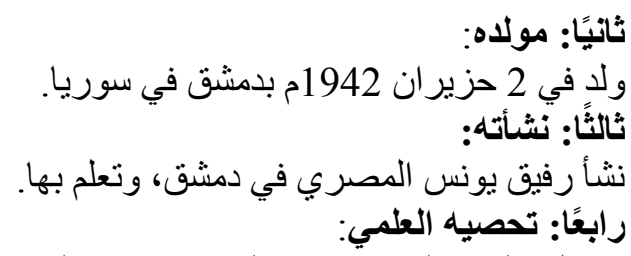

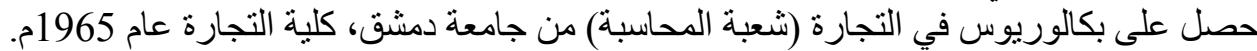

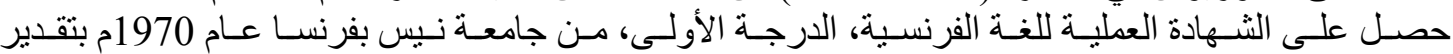

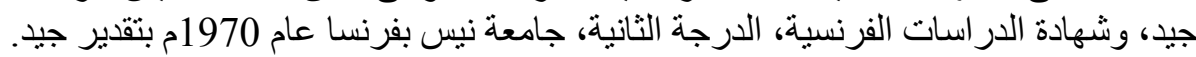

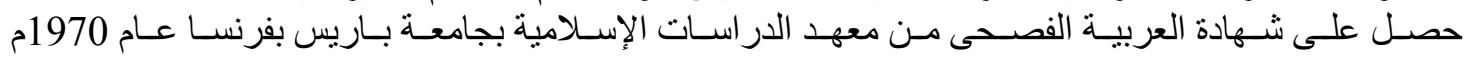
بتقدير جيد.

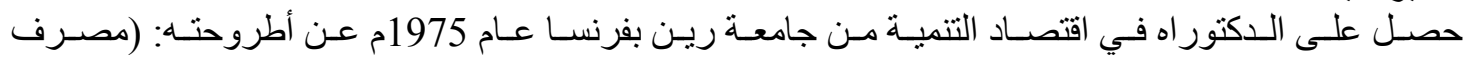
التنمية الإسلامي: محاولة جديدة في الرباو الفائدة والبنك).

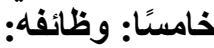

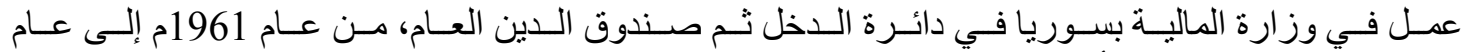

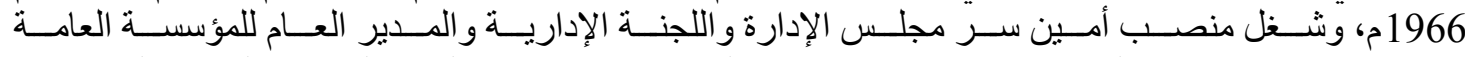

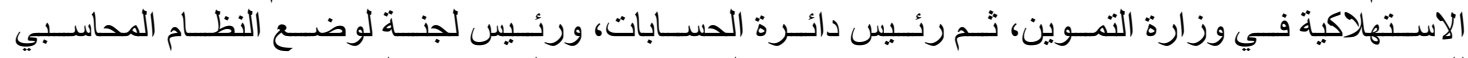

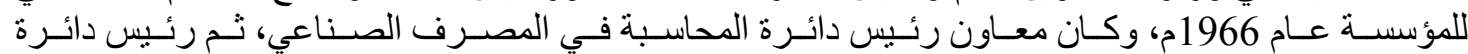

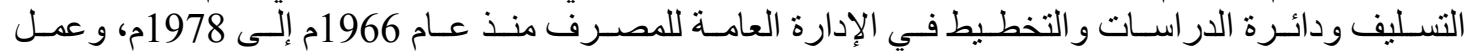

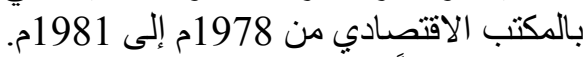

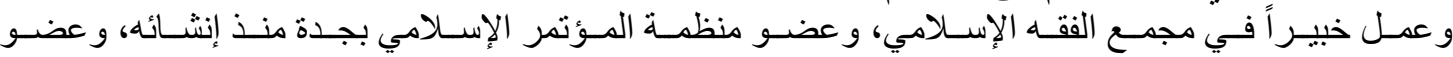

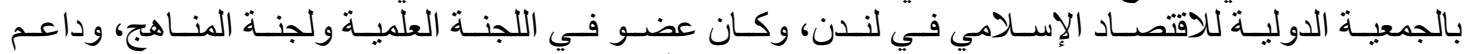

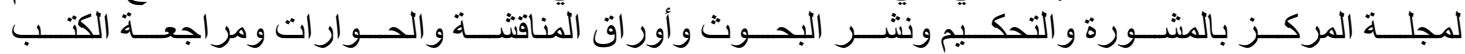

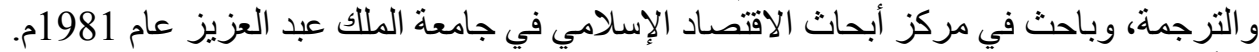

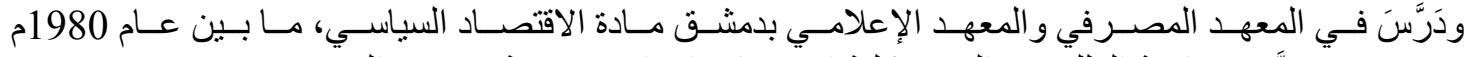

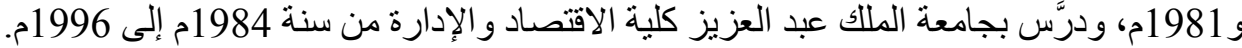

أذكر فيما يأتي مؤلفات الدكتئت الأنتور رفيق يونس المصري بحسب سنو ات صدرو ها:

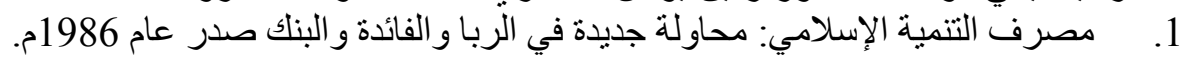

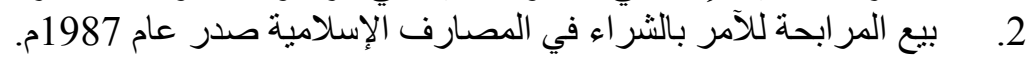
3.

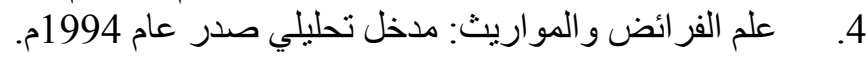

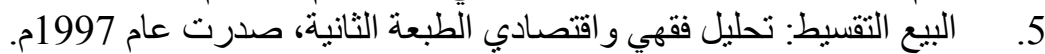

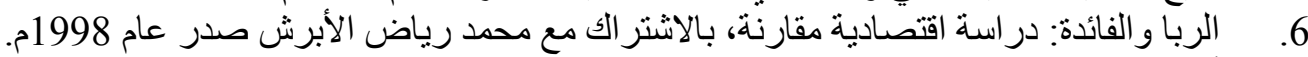
7.

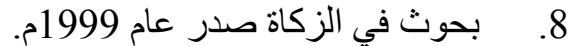
9. بحوث في فقه المعاملات المالية صدر عام عام 1999م.

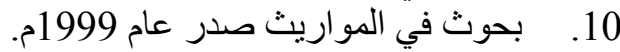

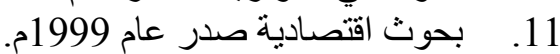

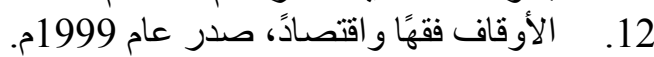

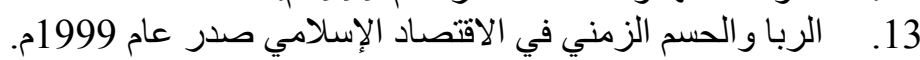

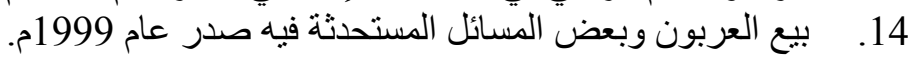




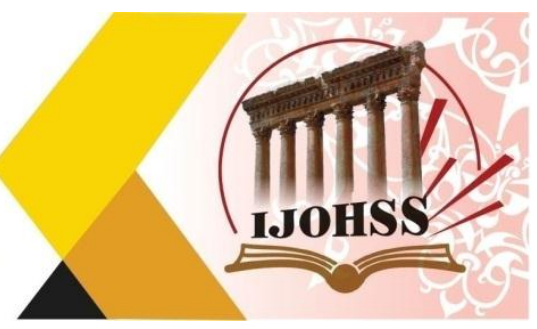

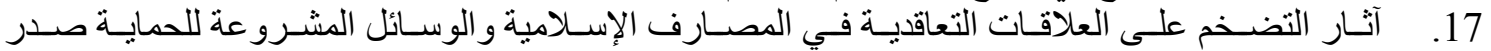

عام 1999م.

18. مناقصنات العقود الإدارية: عقود التوريد ومقاو لات الأشغال العامة صدر عام 1999مام 1999م.

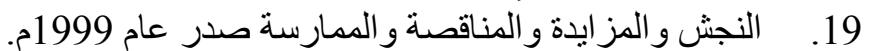

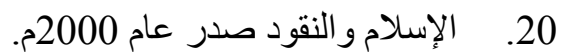

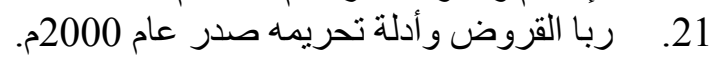

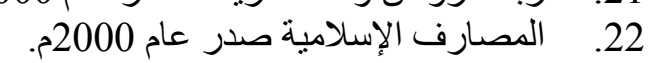

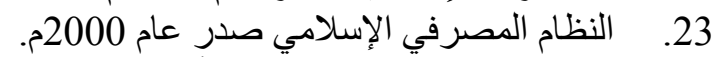

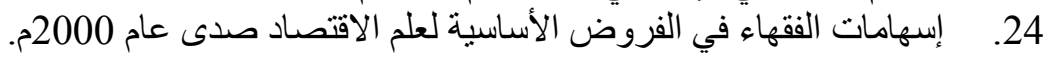

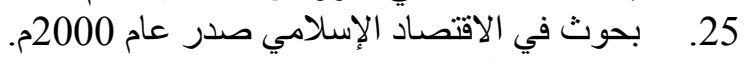

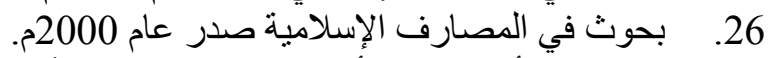
26.

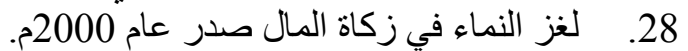

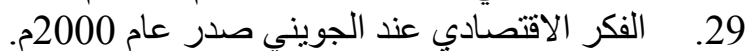

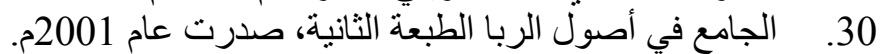

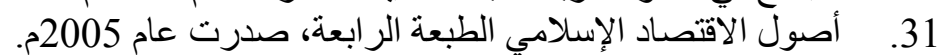

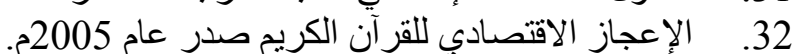

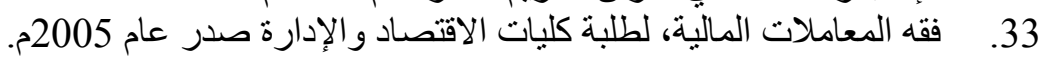

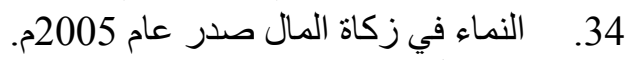

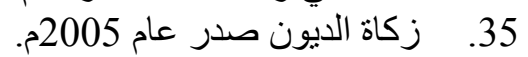

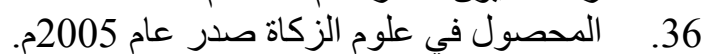

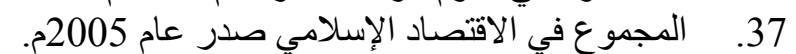

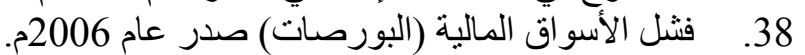

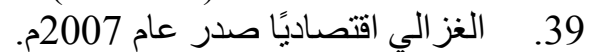

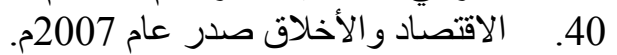

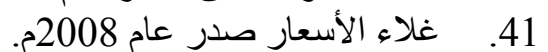

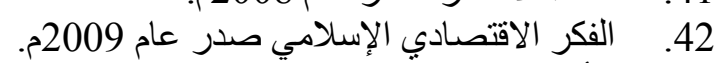

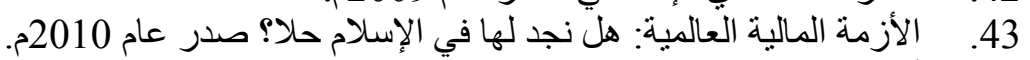

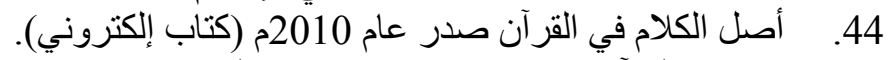

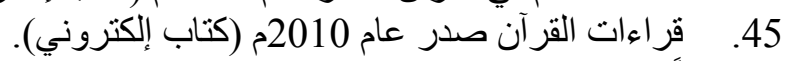

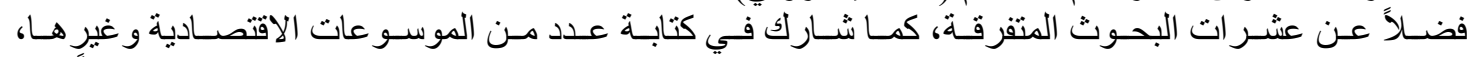

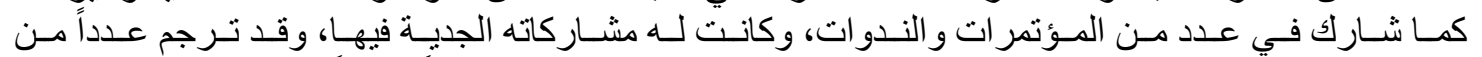

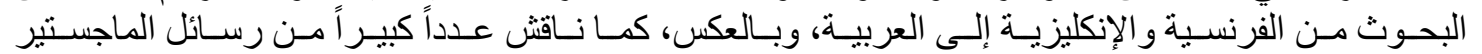

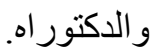

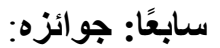

حصل الدكتور رفيق يونس المصري على الزئ عدة جو ائز منها:

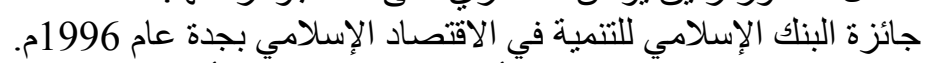

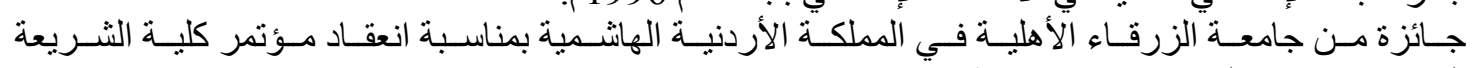
السادس: قضايا مالية معاصرة من منظور إسلامي الأسل 2004م. 


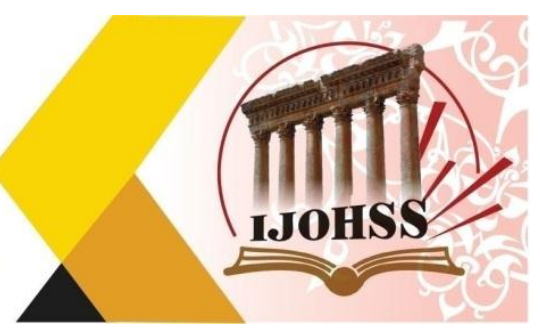

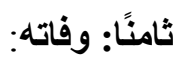

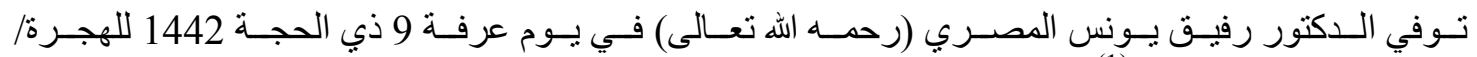

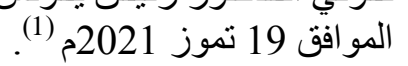

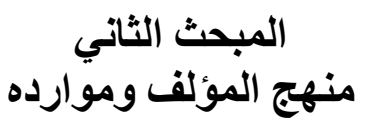

هذا المبحث مكرس لبيان منهج الدكتور رفيق وموارده في تفسره الاقتصادي:

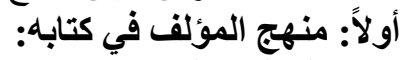

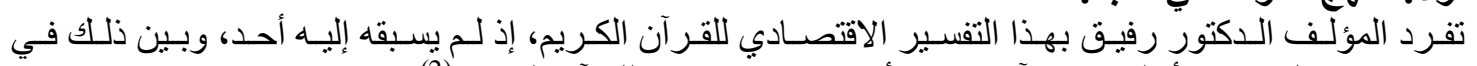

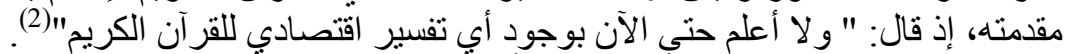

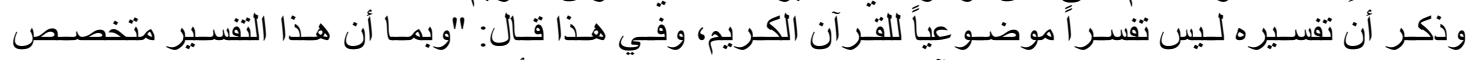

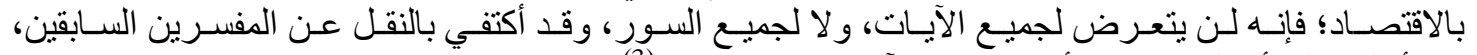

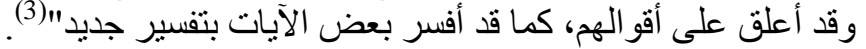
و المنهج الذي اتبعه في تفسيره كان كالآتي:

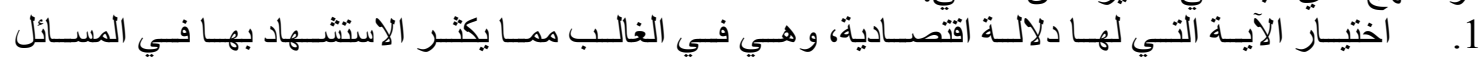
الاقتصادية.

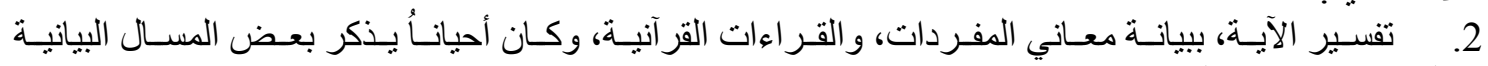
و البلاغية، ومعاني العبار ات. 3.

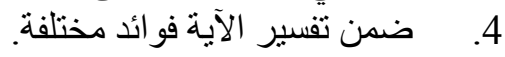

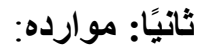

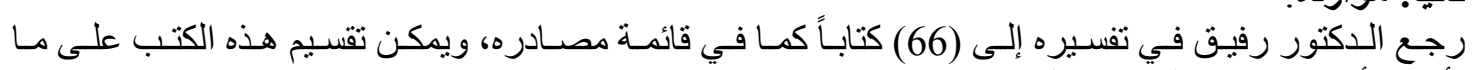
يأتي، وأرتبها بحسب الدكر رفئ في تفروف الهجائية:

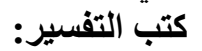
1 2. 3. 4. 5.

(1) ينظر : سيرة ذاتية. مدونة د. رفيق المصري، https://drmasri.wordpress.com/author/drmasri/ ؛ موسوعة

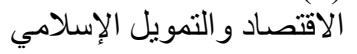

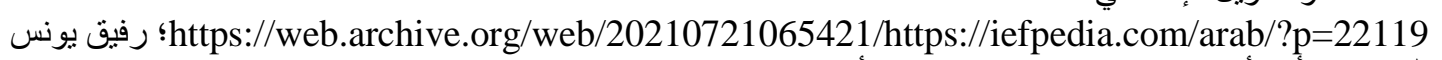
المصري. أحد أعلام الاقتصاد الإسلامي. إسلام أون لاين https://web.archive.org/web/20210814222324/https (2) التفسير الاقتصادي للقرآن الكريم، الدكتور رفيق يونس الدصري، دار القلم، دمشق، 1434هـ 2013م: 5. (3) (3) (3) المرجع نفسه: 5. 


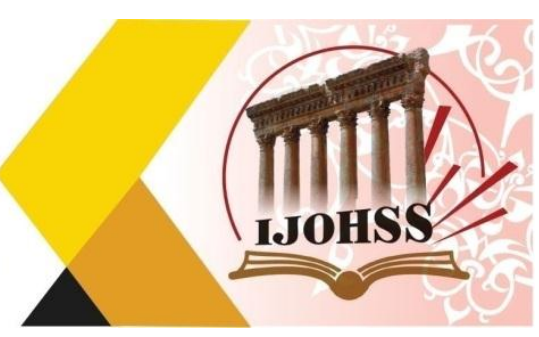

6. تفسير القرآن العظيم، لابن كثير (ت774هـه). 7. 8.

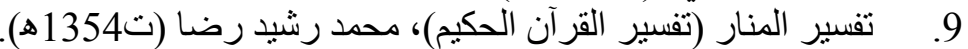

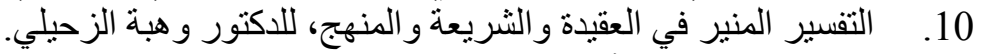

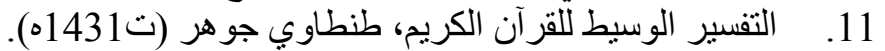

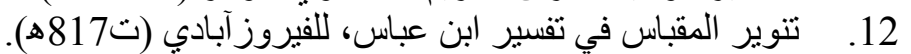

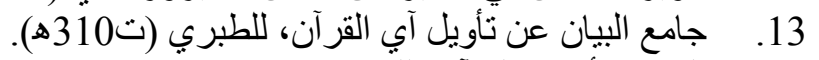

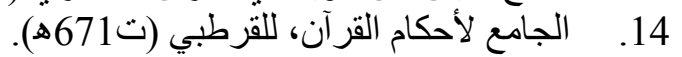

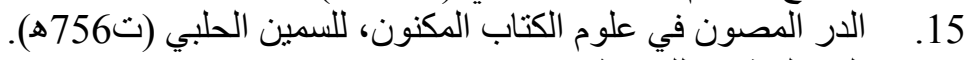

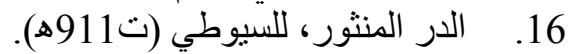

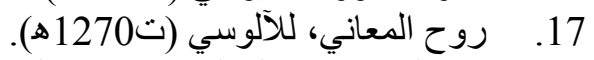

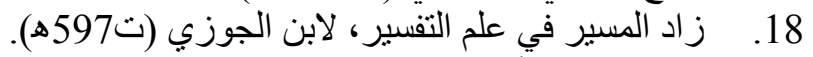

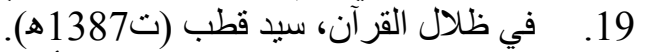

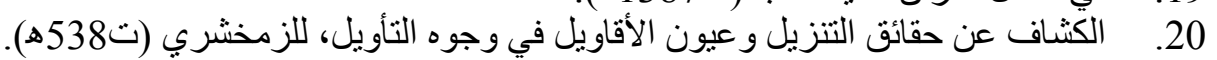

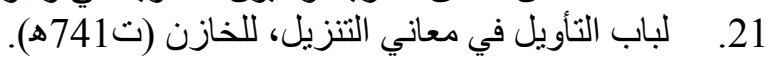

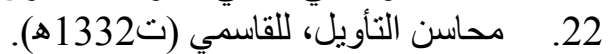

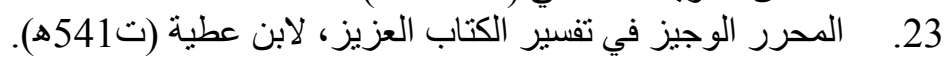

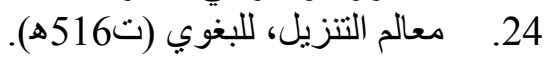

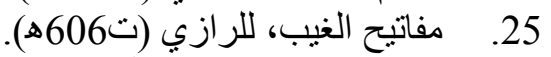

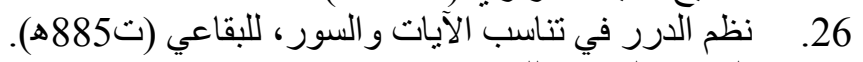

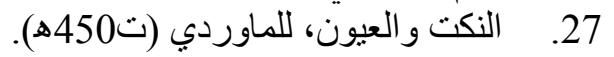

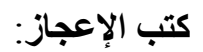

28. دلائل الإعجاز في علم المعاني، للجرجاني (ت ألإنهـه).

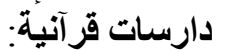

29. علوم القرآن الكريم:

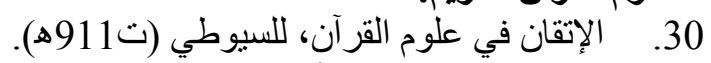

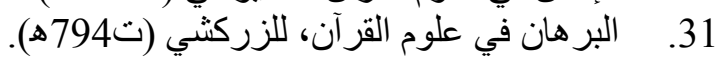

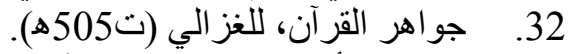

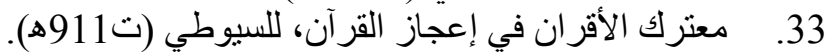

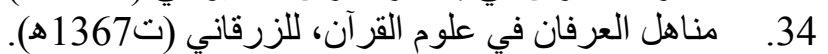
كتب الحديث: 35. - 35

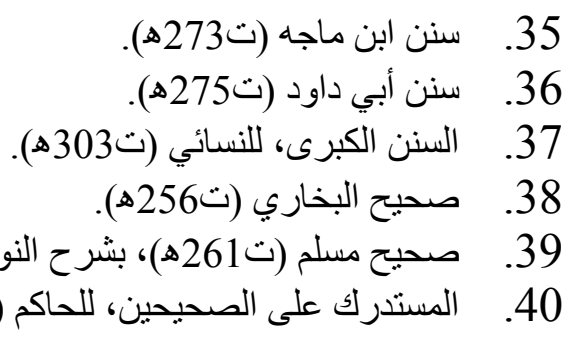




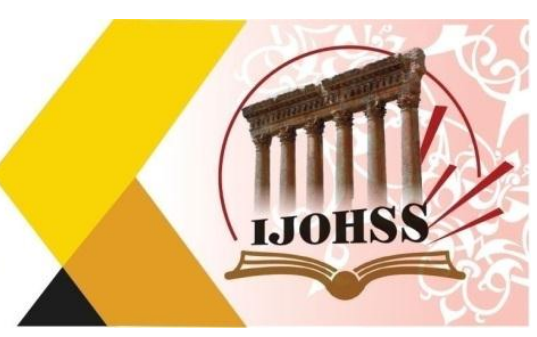

كتب إسلامية عامة:

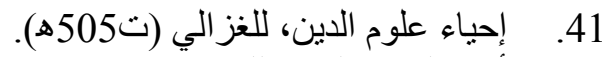

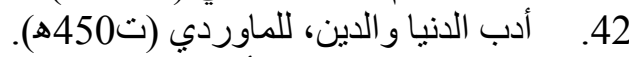

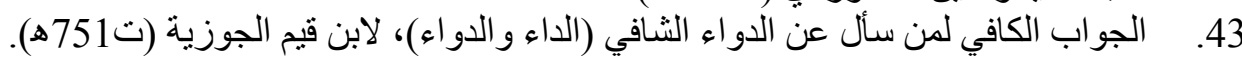

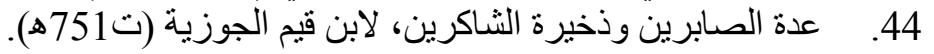

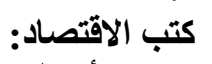

45. الأموال، لأبي عبيد (ت224هـ).

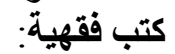

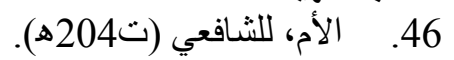

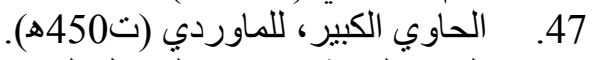

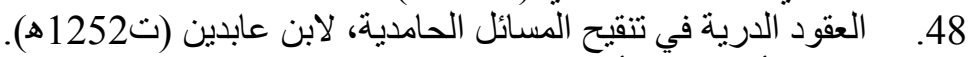

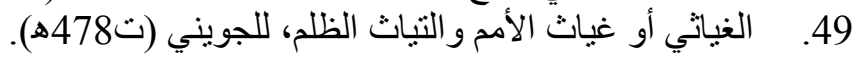

50.

51.

52.

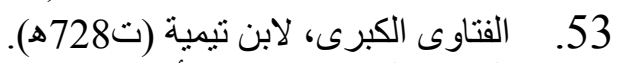

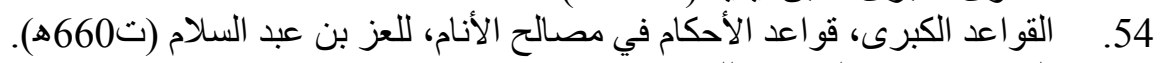

55.

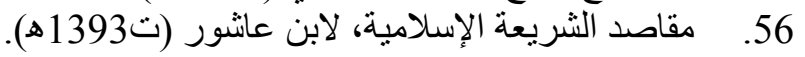

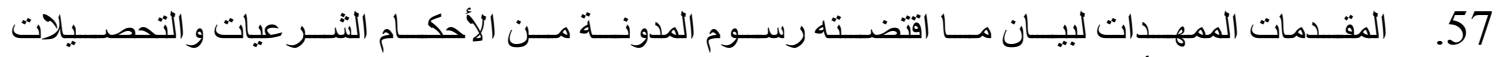

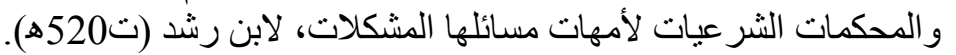

58. الموسو عة الفقهية.

مؤلفات المؤلف نفسه:

59. إسهامات الفقهاء في الفروضه الفوض الأساسية لعلم الاقتصاد.

60 60 أصول الاقتصاد الإسلامي.

61 60. الإعجاز الاقتصادي للقرآن الكريم.

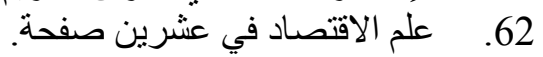
63. الفكر الاقتصادي الإسلامي.

64. المذاهب الاقتصادية و الاقتصاد الإسلامي.

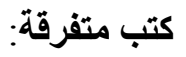

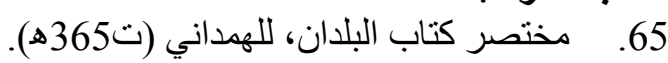

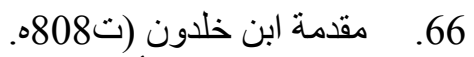

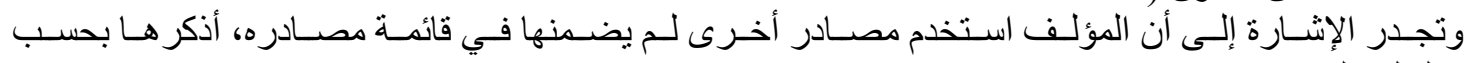

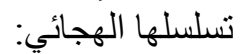

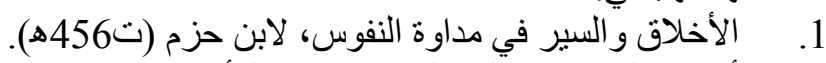

2.

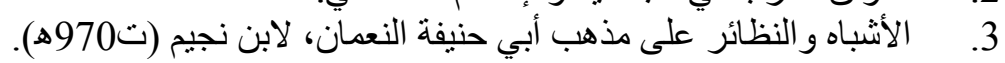

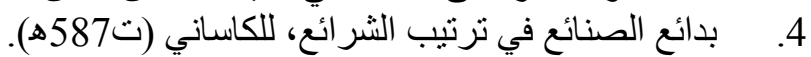

5.

6. تحرير الكلام في مسائل الالتزام، للحطاب (تهد). 


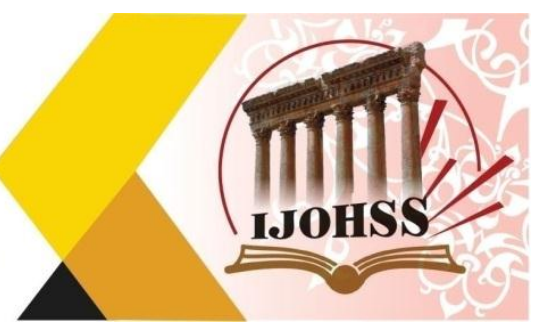

$$
\begin{aligned}
& \text { 7. التعريفات، للجرجاني (ت 816ه). } \\
& \text { 8. }
\end{aligned}
$$

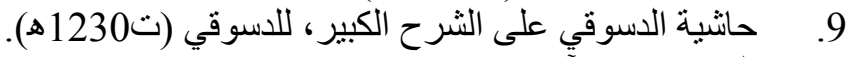

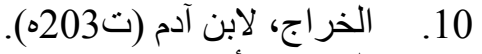

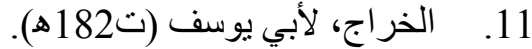

$$
\begin{aligned}
& \text { 12. الدين الخالص أو إرشاد الخلق إلى دين الحق، لمحمود السّبكي. }
\end{aligned}
$$

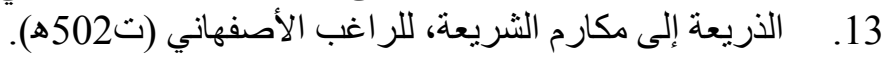

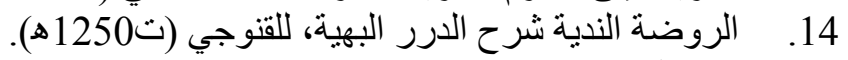

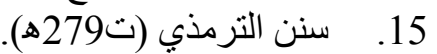

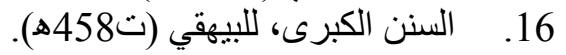

$$
\begin{aligned}
& \text { 17. } \\
& \text { 18. } \\
& \text { 19. }
\end{aligned}
$$

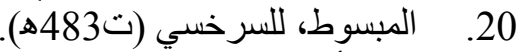

$$
\begin{aligned}
& \text { 21 . 20. مسند أحمد (241). } \\
& \text { 22. المشرو عية في النظام الإسلامي، مصطفى كمال وصفي. }
\end{aligned}
$$

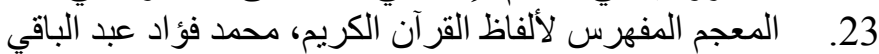

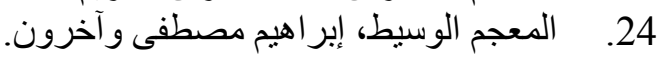

$$
\begin{aligned}
& \text { 25. }
\end{aligned}
$$

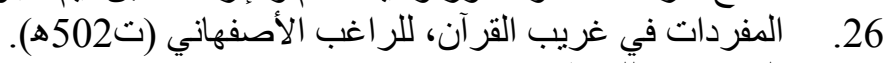

$$
\begin{aligned}
& \text { 27. }
\end{aligned}
$$

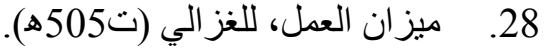

$$
\begin{aligned}
& \text { 29. } \\
& \text { ثالثاً: منهجه في الوثيق: }
\end{aligned}
$$

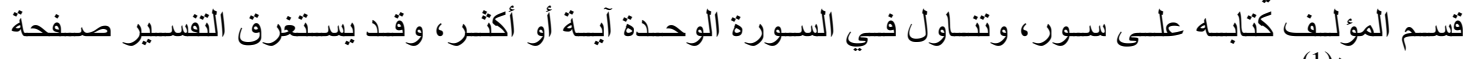

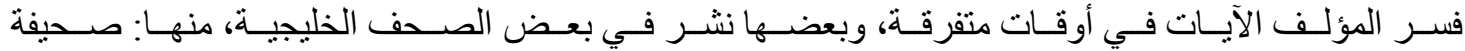

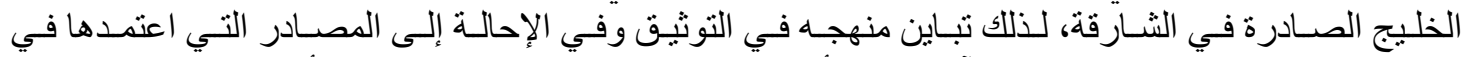

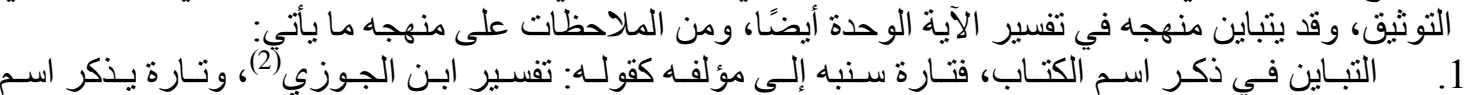

(1) مثال ذلك تفسير الآية 124 من سورة طه. ينظر : التفسير الاقتصادي للقر آن الكريم: 169.

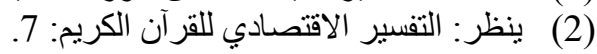
(3) بنظر: المرجع نفسه: 49.

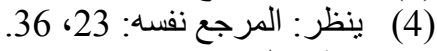
(5) بنظر: المرجع نفسه: 12، 18، 18، 25 (5)، 


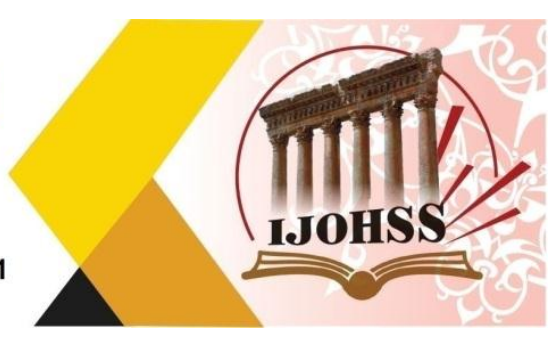

4. كان يذكر مصادره أحباناً في متن الكتاب(1).

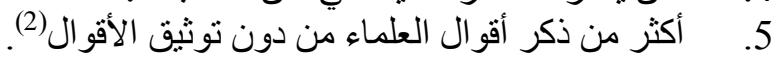

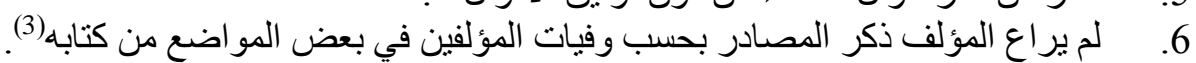

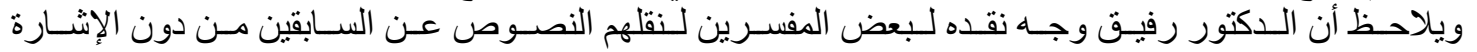
إلى ذللك، من ذلك: التل

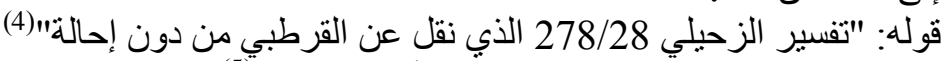

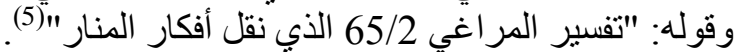

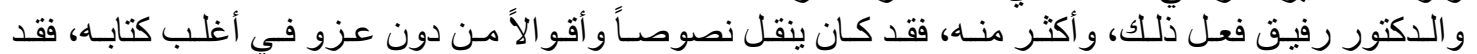

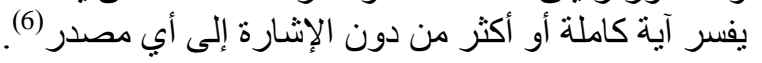

\section{المبحث الثالث \\ جهوده التفسيرية التمبت}

يمكن الوقوف على الجهود التفسيرية للاكتور رفيق في المسائل الآتية:

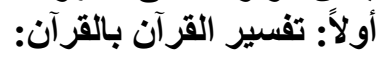

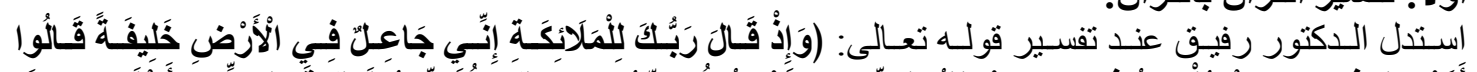

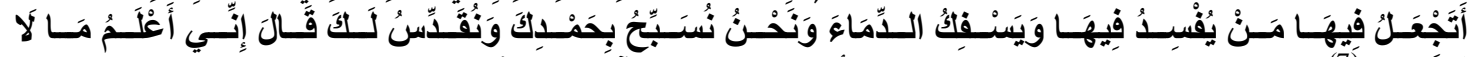

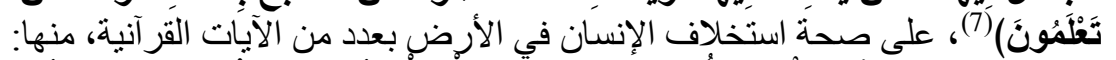

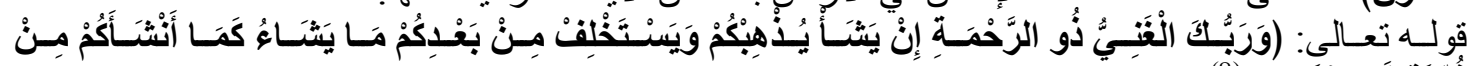

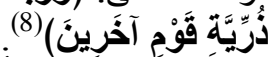

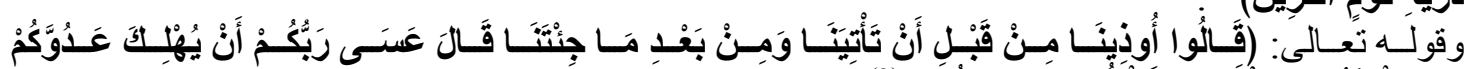

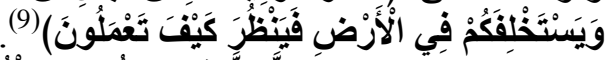

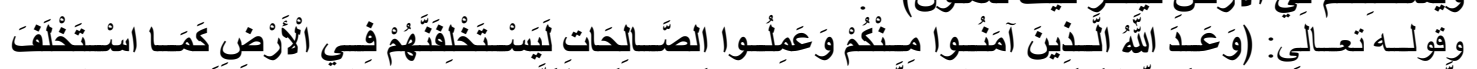

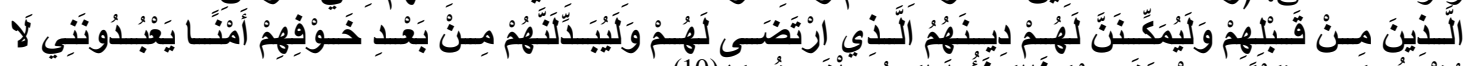

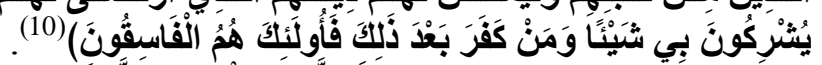

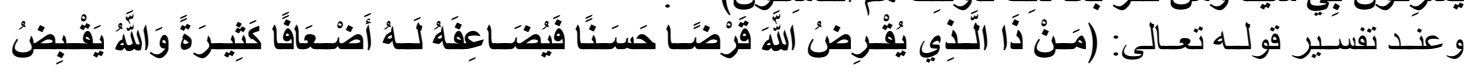

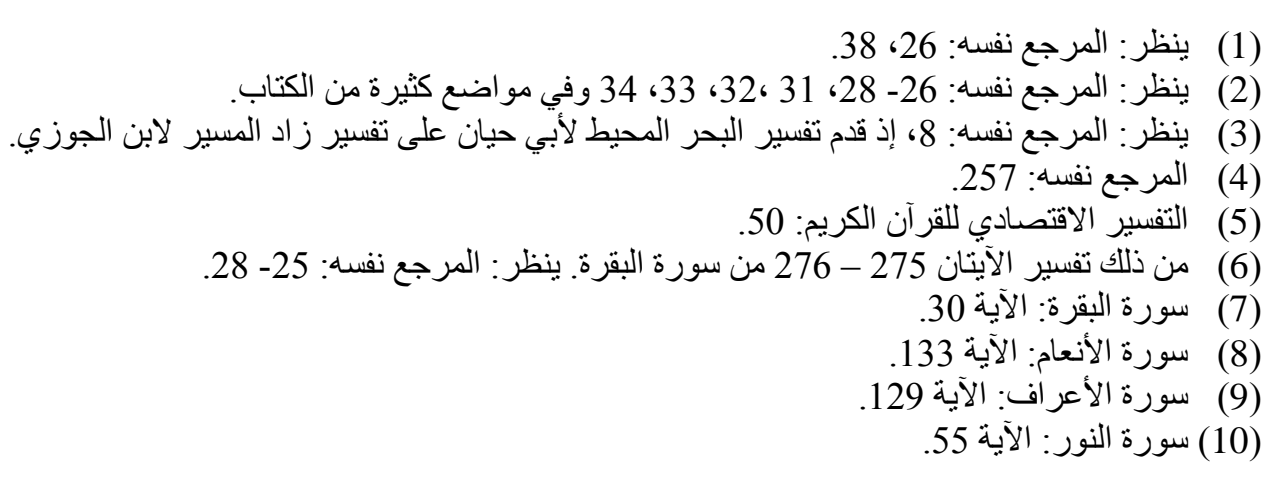




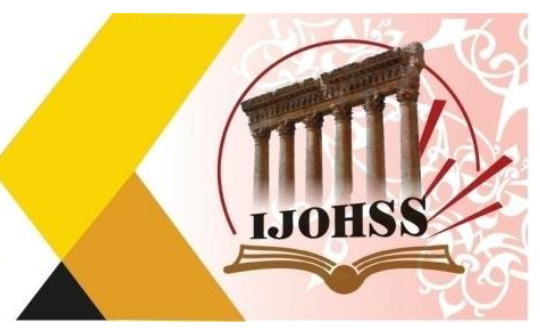

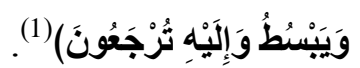

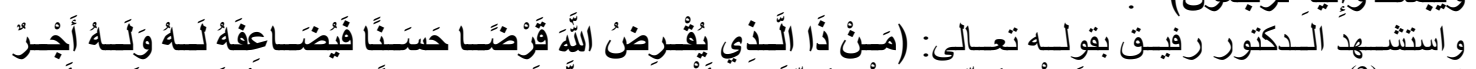

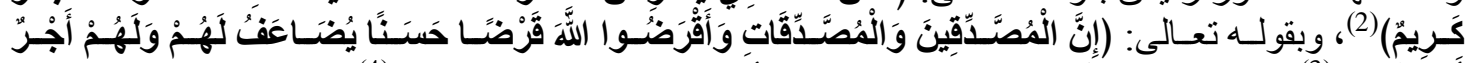

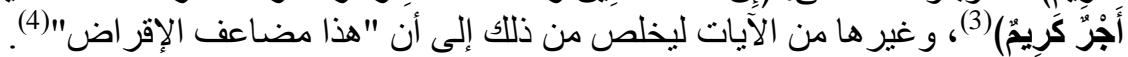

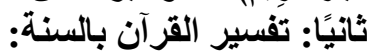

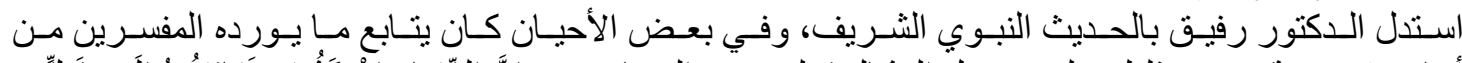

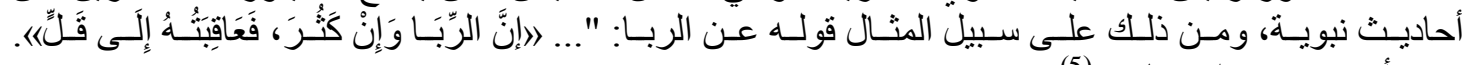

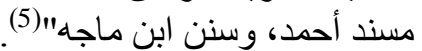

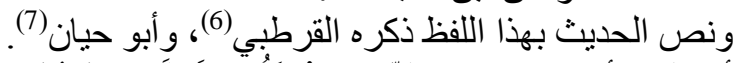

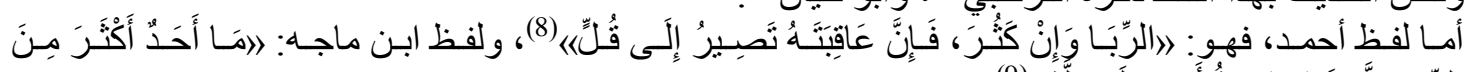

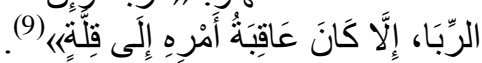

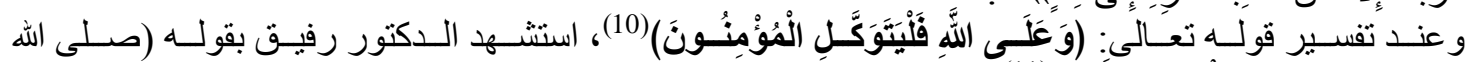

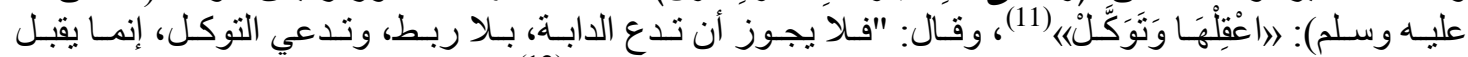

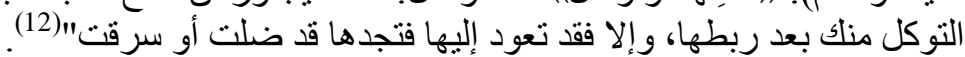

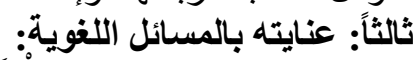

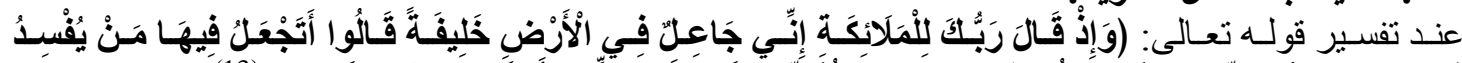

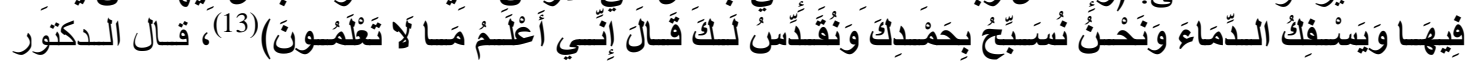

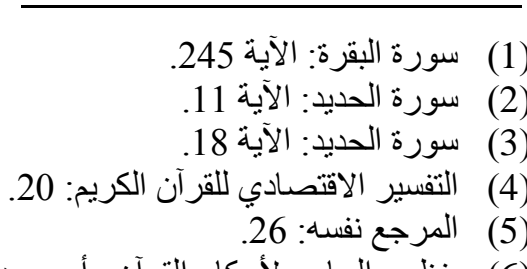

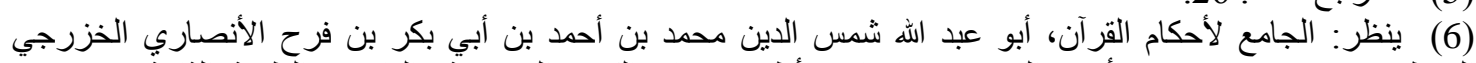

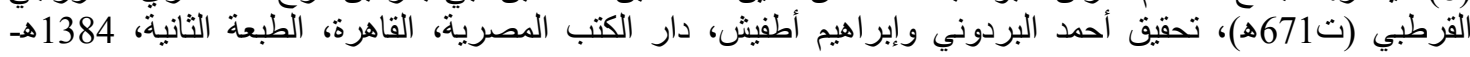
1964م: 362/3.

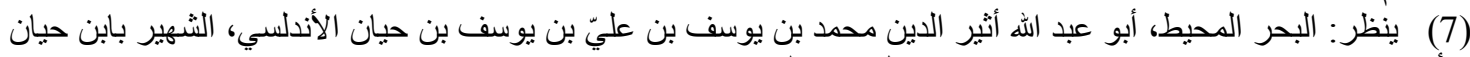

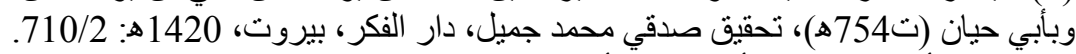

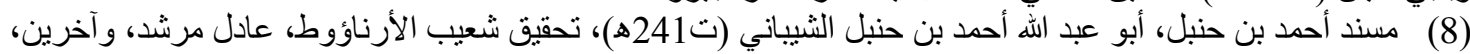
مؤسسة الرسالة، بيروت، 1421هـ 2001م: 297/6، رقم (3754). من حديث ابن مسعود (رضي الله عنه). قال الثنيخ

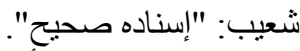

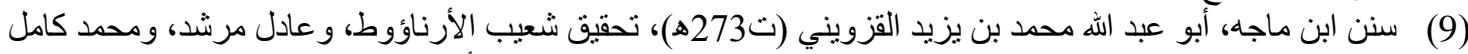

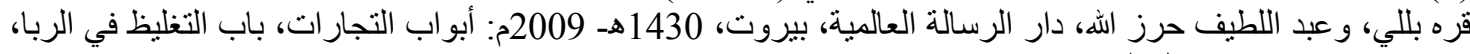

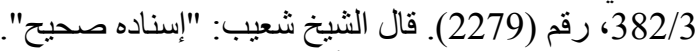

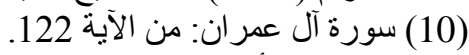

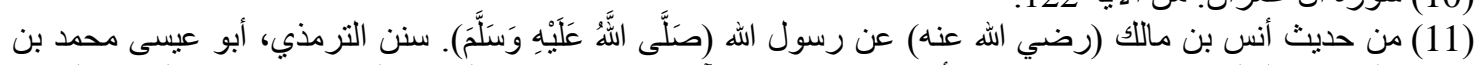

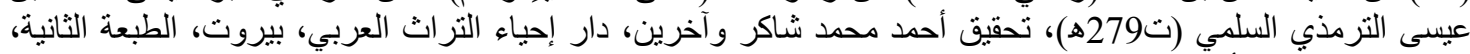

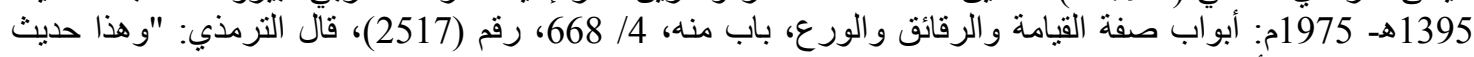

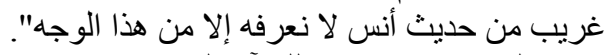

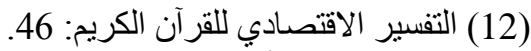

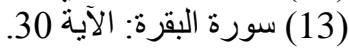




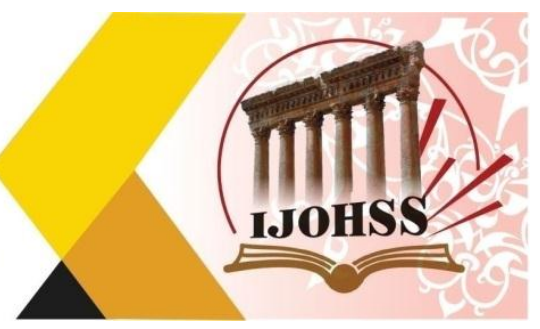

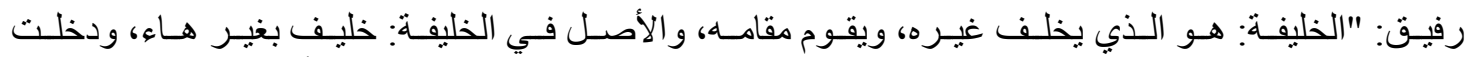

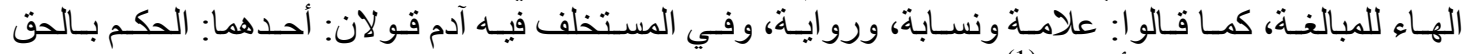

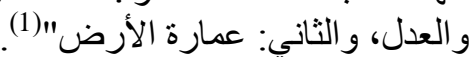

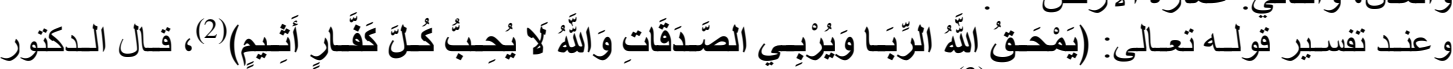
رفيق: "يمق: يذهب، يزيل، يمحو" (3). .

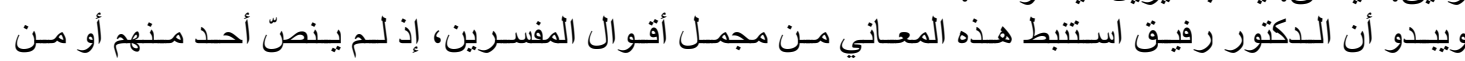
اللغوين على هذه المعاني مجتمعة.

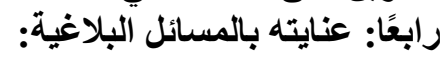

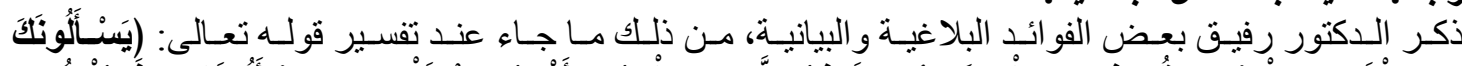

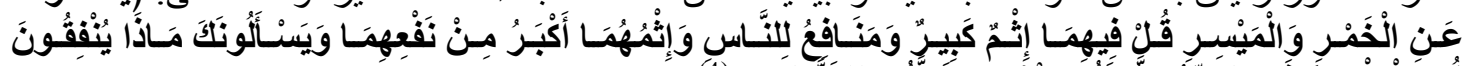

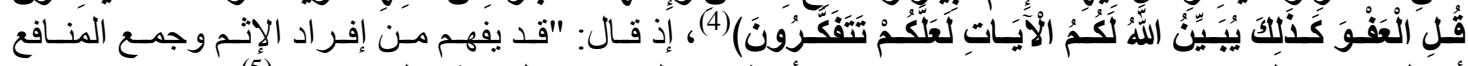

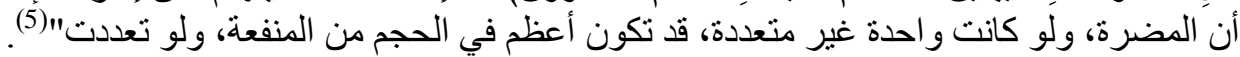

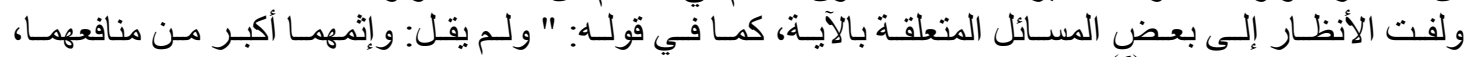

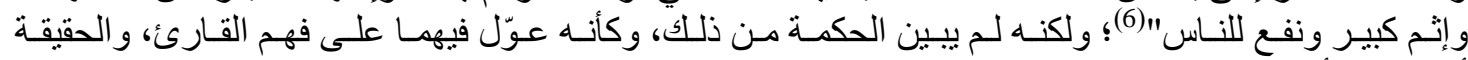

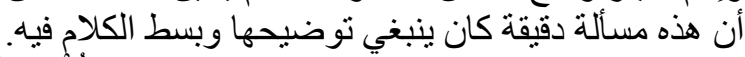

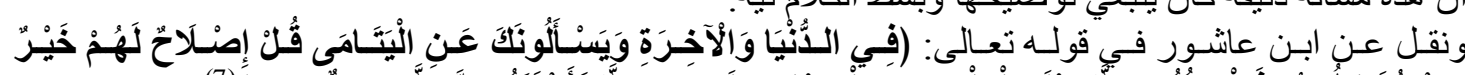

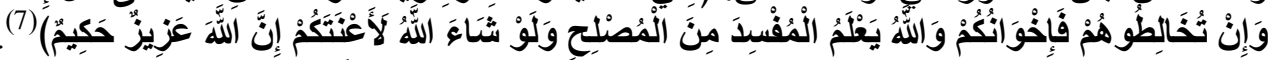

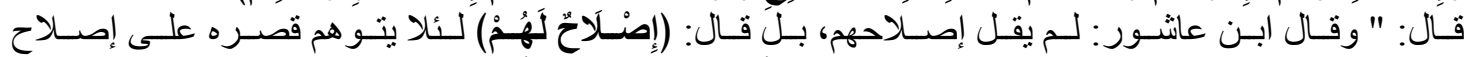

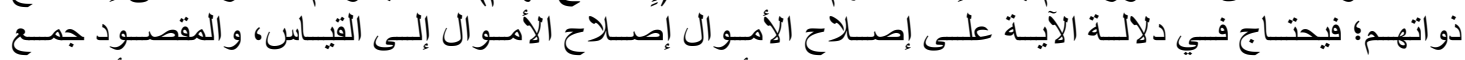

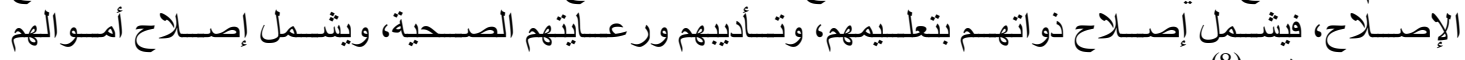

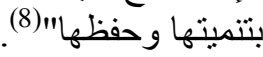

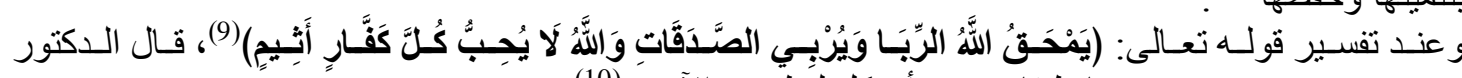

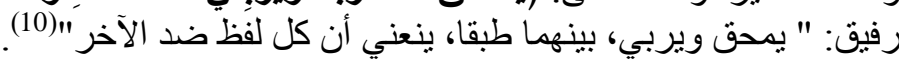

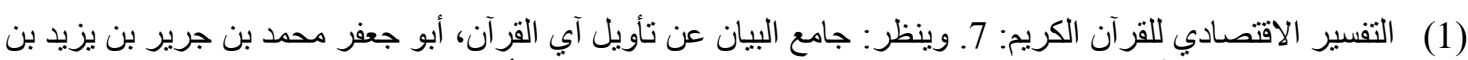

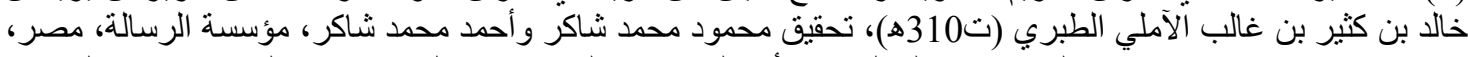

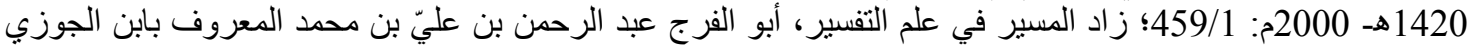

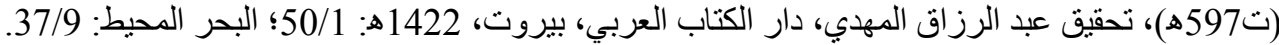

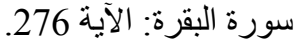
التفسير الاقتصادي للقرة آن الكريم: 26.

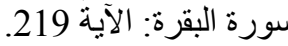

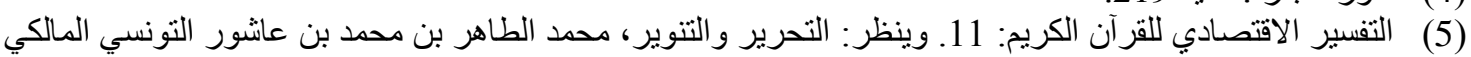
(ت1393ه)، الدار التونسية للنشر ، تونس، 1404 هـ 1984مئ 1984م: 37/8.

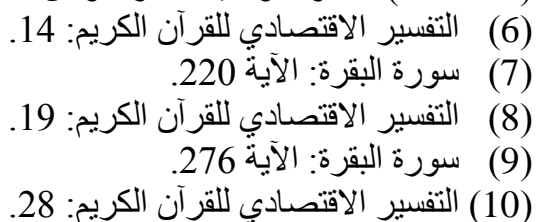




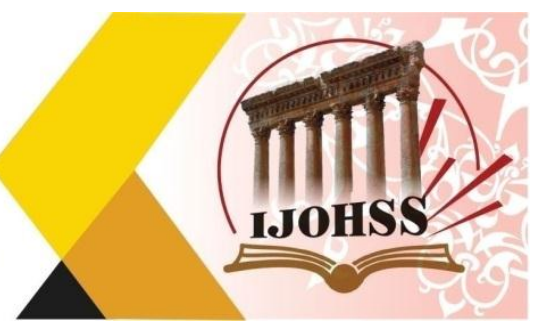

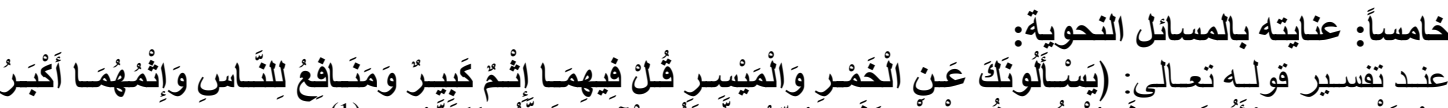

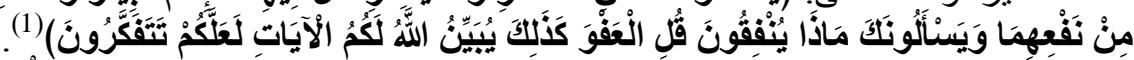

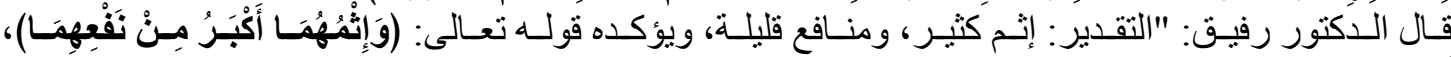
أو ضرر كبير ومنافع قليلة.

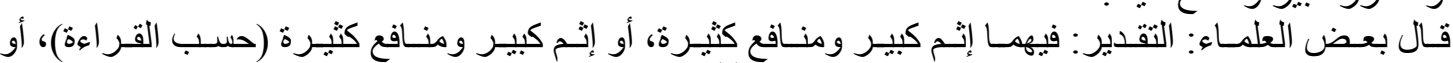
مضار كثيرة ومنافع كثيرة، أو آثام كثيرة ومنافع كثيرة" (2).

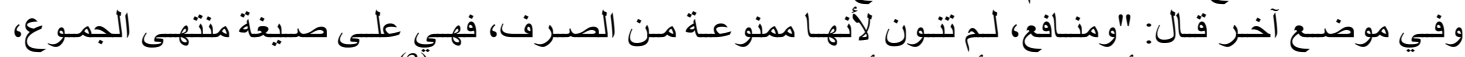

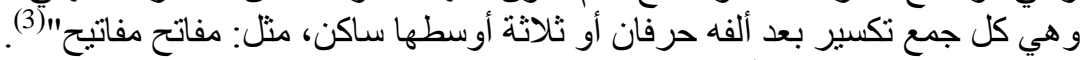
سادسًا: القراعات القرآنية:

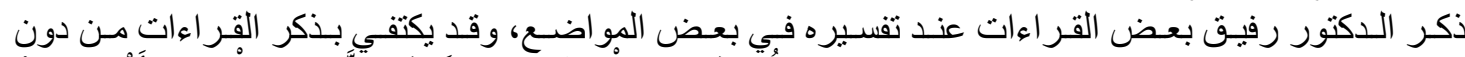

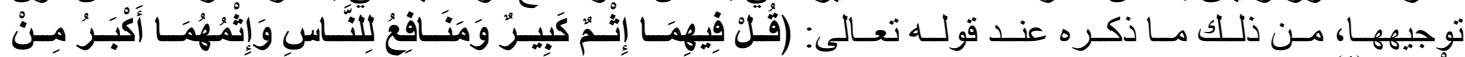

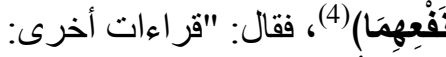
إنثيّ كثنير.

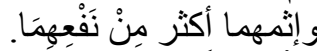

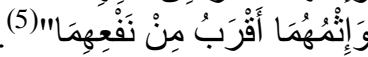

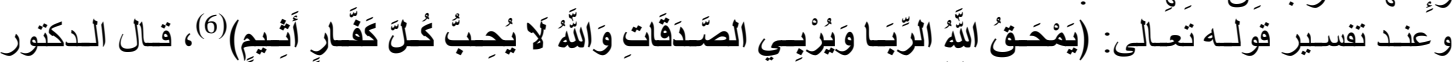

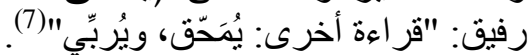

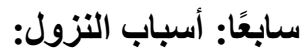

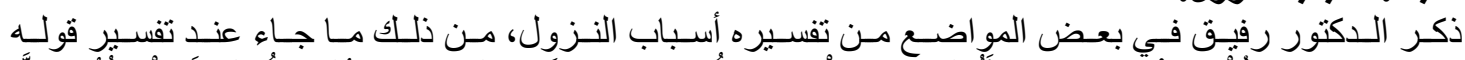

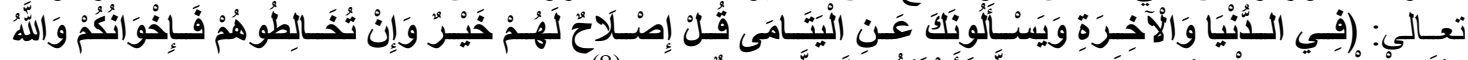

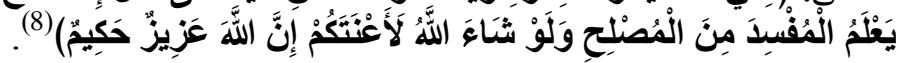

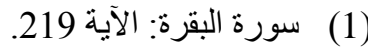

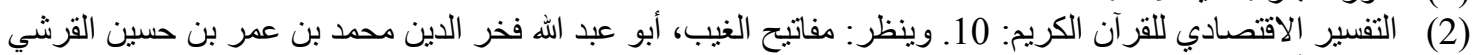

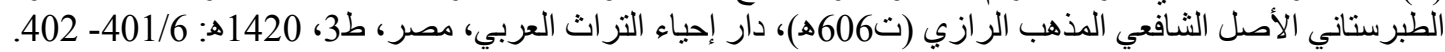

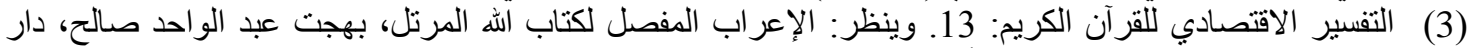

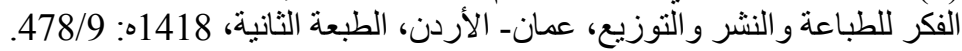
(4) - (4) سورة البقرة: من الآية الإية 219.

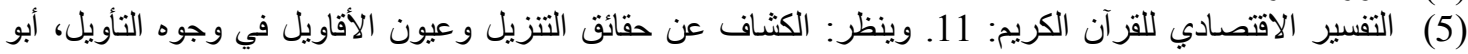

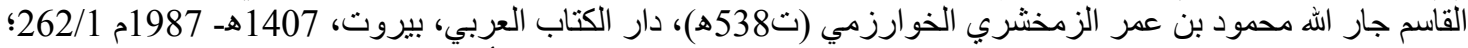

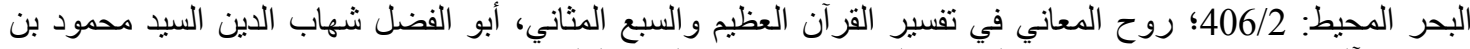

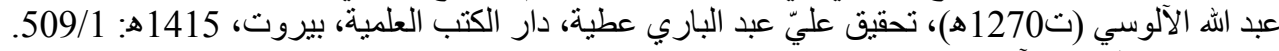

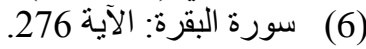

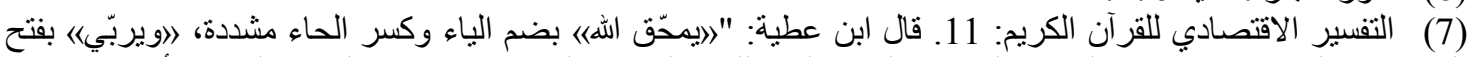

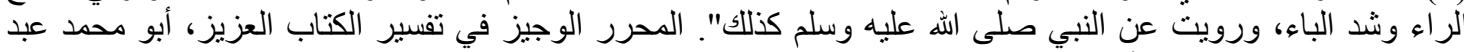

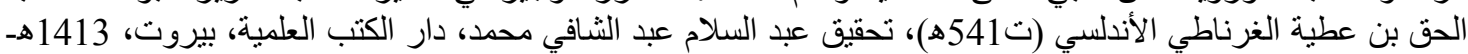




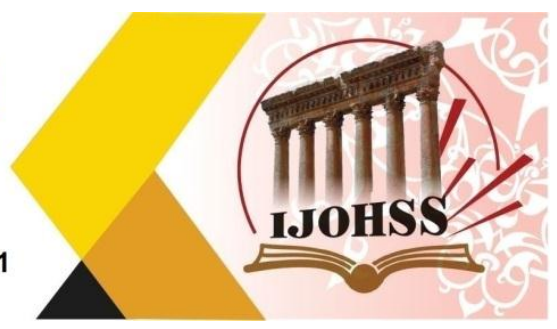

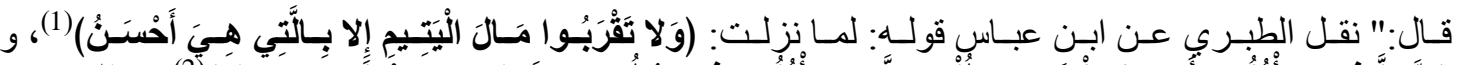

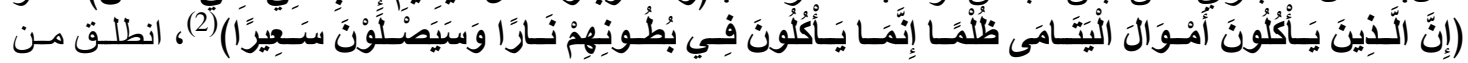

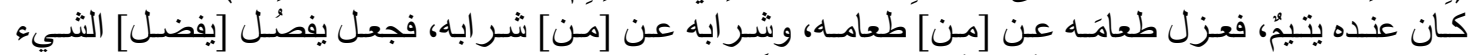

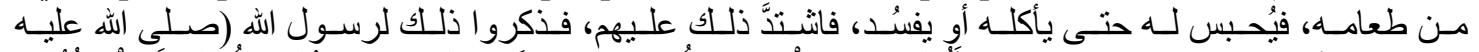

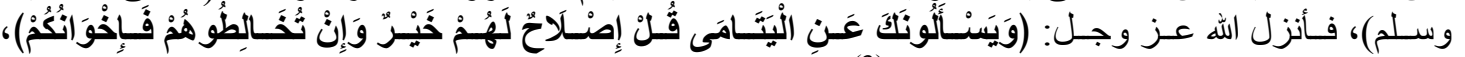

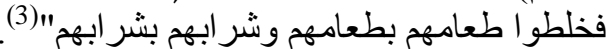
ثامنًا: استثهاده بالثعر:

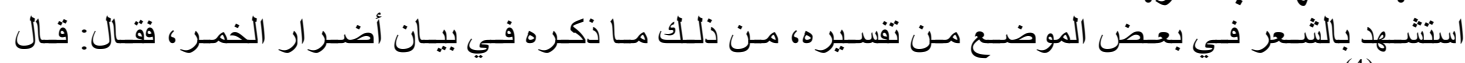

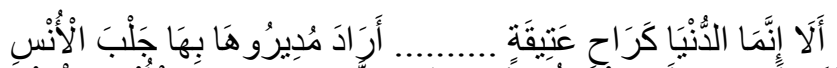

الثناعر (4): (2) (2)

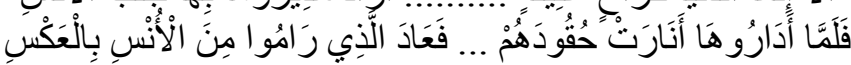

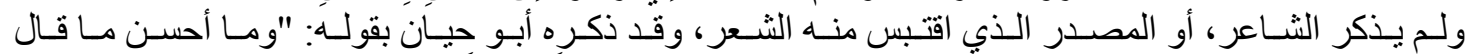

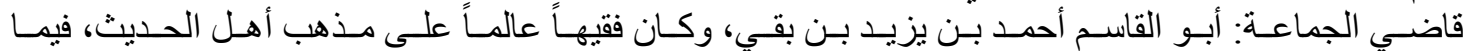

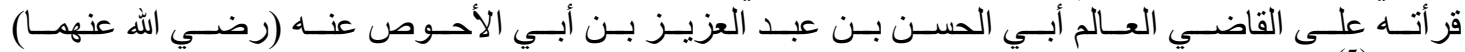
بكرمه" (5). ثم ذكر البيتين.

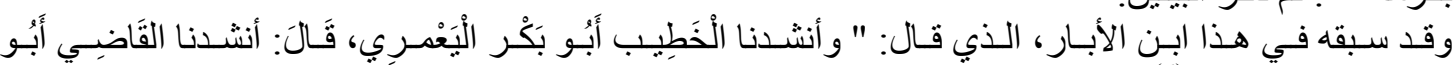

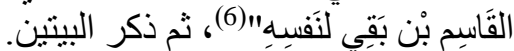

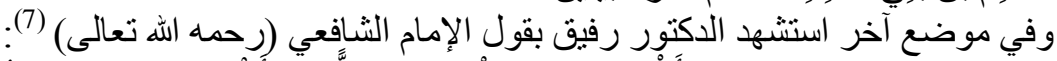

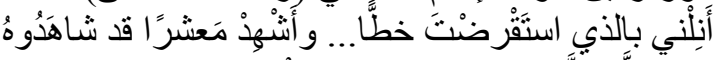

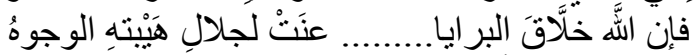

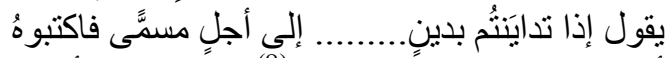

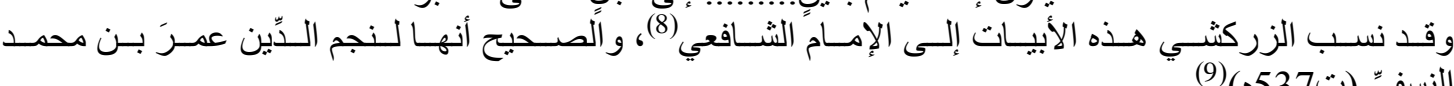
النسفيّ (ت537ه)

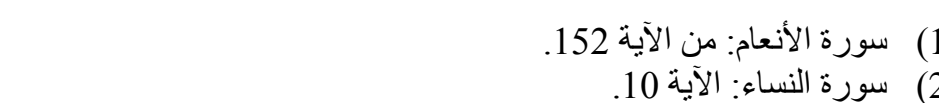

التفسبر الاقتصادي للقرآن الكريم: 18 - 19. وينظر : جامع البيان: 350/4. المرجع نفسا: 16.

البحر المحيط:

(6) التكملة لكتاب الصلة، أبو عبد الله محمد بن عبد الله بن أبي بكر القضاعي البلنسي المعروف بابن الأبار، (658هـ)،

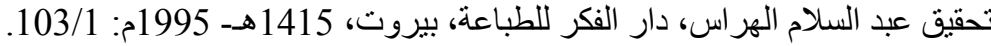

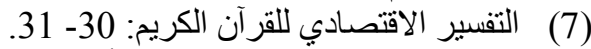
(8) ينظر: البرهان في علوم القرآن، أبو عبد الله بدر الدين محمد بن عبد الله بن بهادر الزركثي الثافعي (ت784هـهـ)،

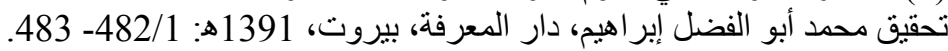

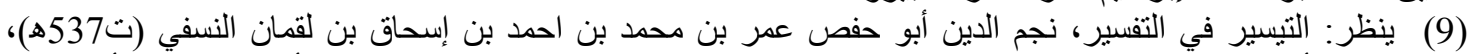

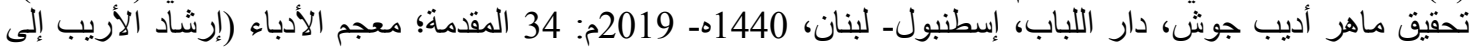

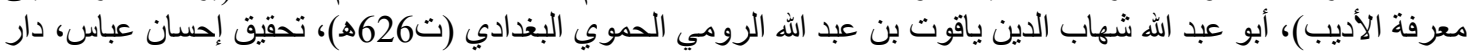

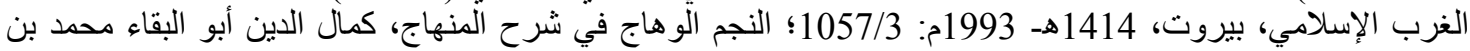

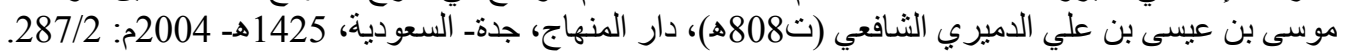


تاسعًا: الفوائد الاقتصادية:

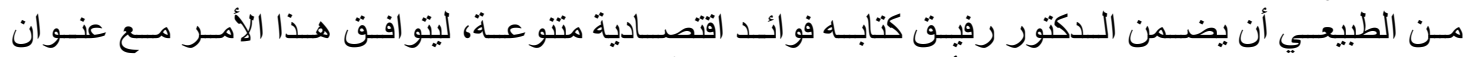

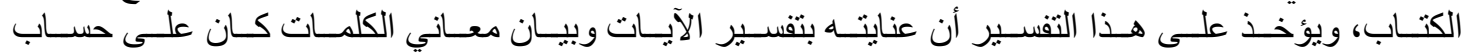

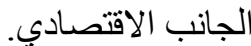

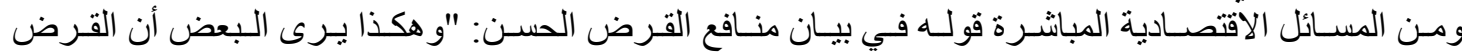

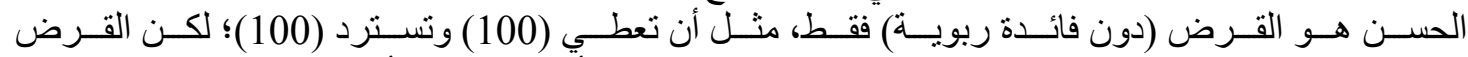

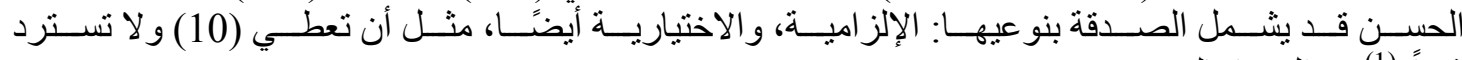

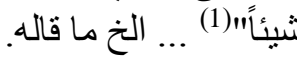

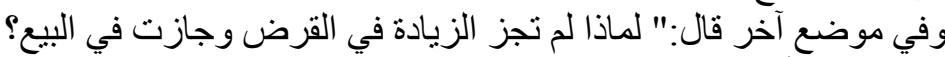

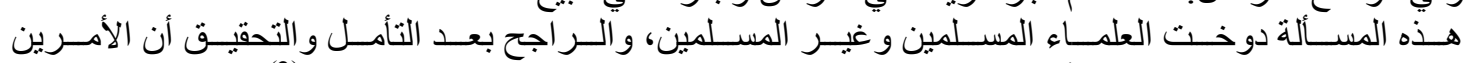
مختلفان في الفقه والاقتصاد؛ لأن المبادلة في القرض العن بين منماتلين، وفي البيع بين مختلفين" (2).

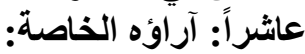

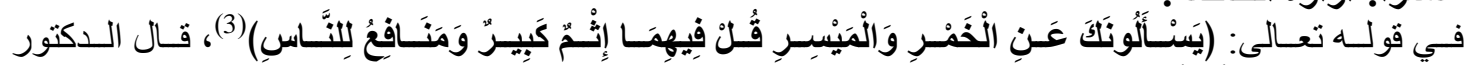

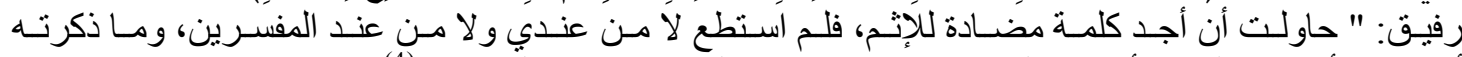

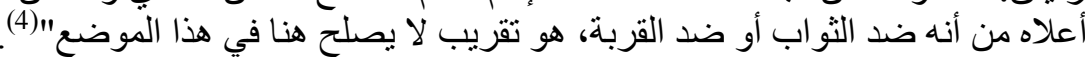

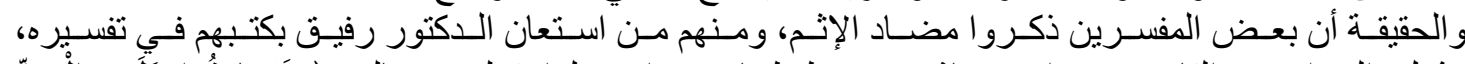

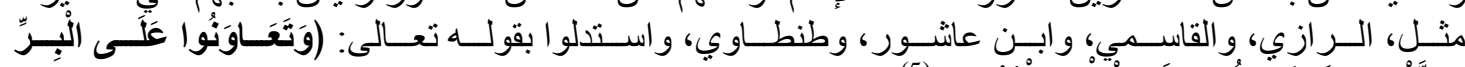

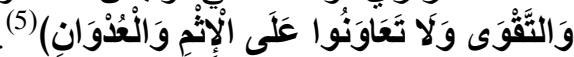

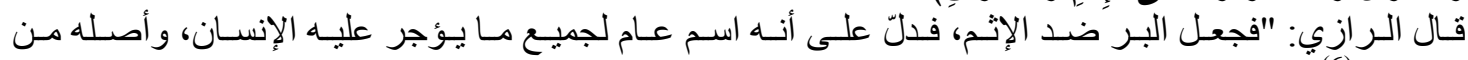

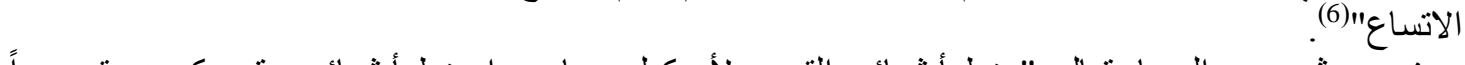

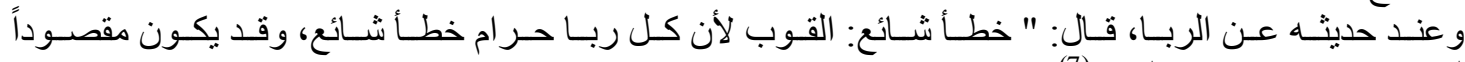

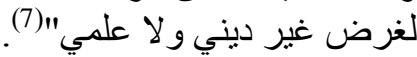

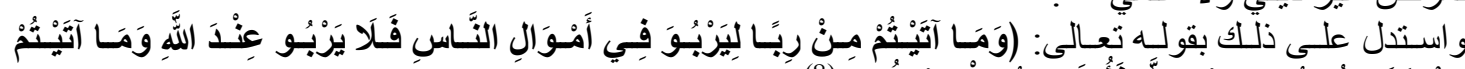

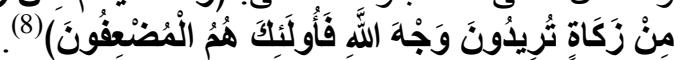

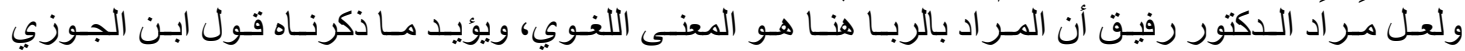

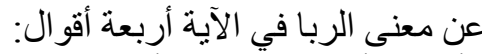

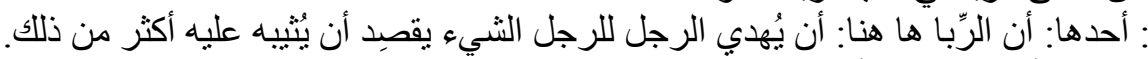
و الثاني: أنه الرِّبا المحرَّم.

$$
\begin{aligned}
& \text { التفسير الاقتصادي للقر آن الكريم: } 22 . \\
& \text { التفسير الاقتصادي للقرآن الكريم: } 24 . \\
& \text { سورة البقرة: من الآية اللية } 219 . \\
& \text { التفسير الاقتصادي للقرة آن الكريم: } 13 . \\
& \text { سورة المائدة: من الآية } 2 .
\end{aligned}
$$

(6) مفاتيح الغيب: 213/5. وينظر: مالغئ: محاسن التأويل، محمد جمال الدين بن محمد سعيد بن قاسم الحلاق القاسمي

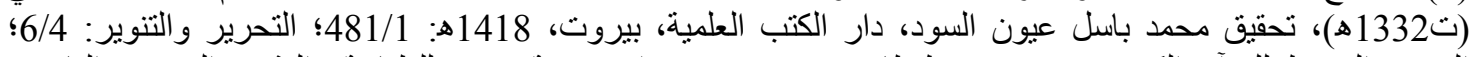

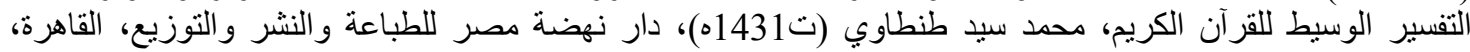




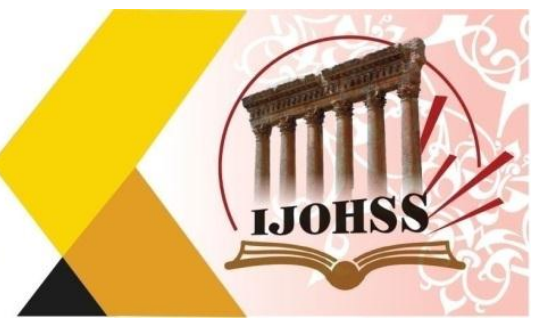

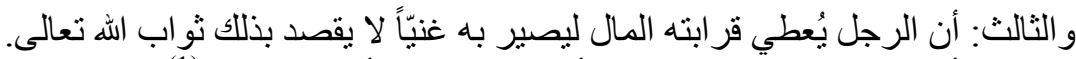

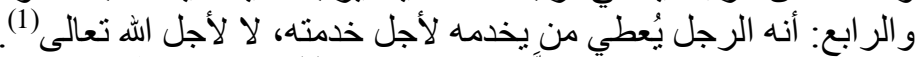

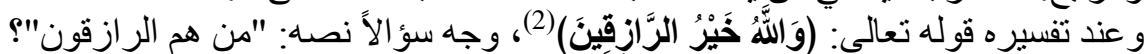

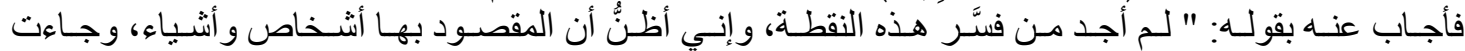

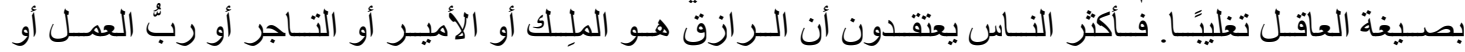

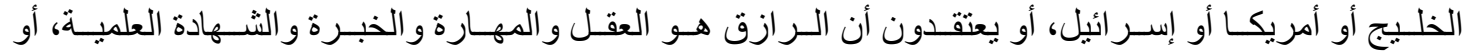

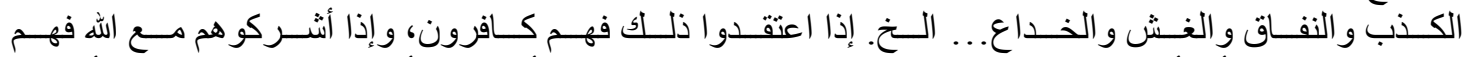

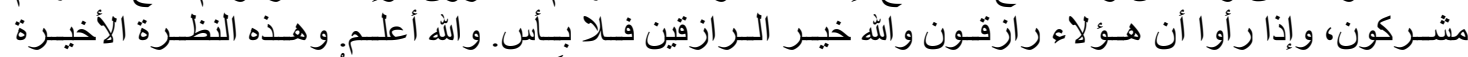

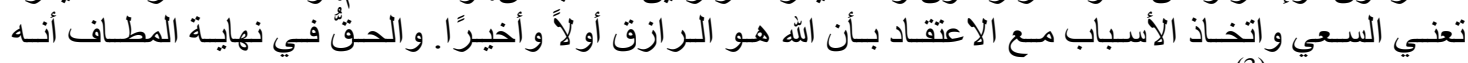

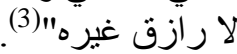

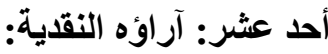

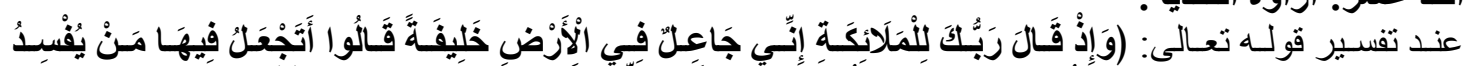

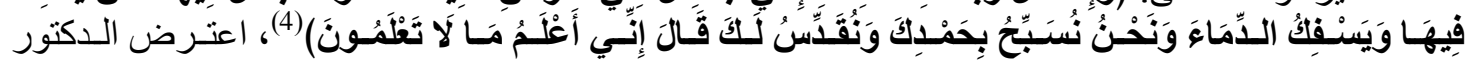

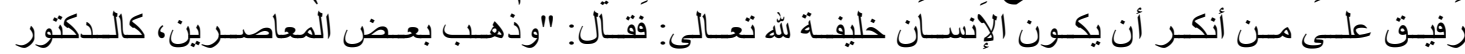

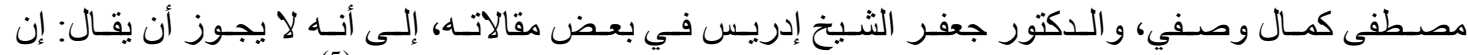

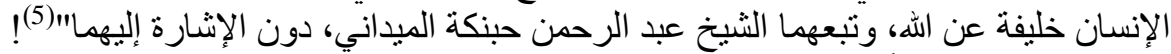

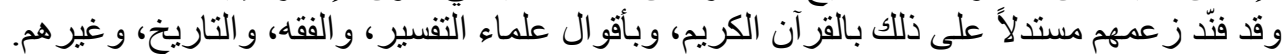

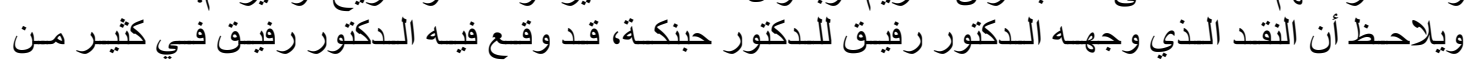

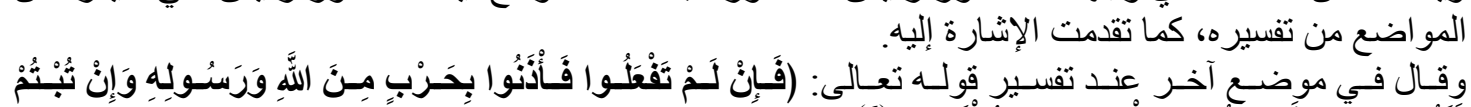

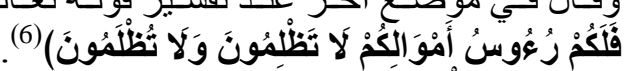

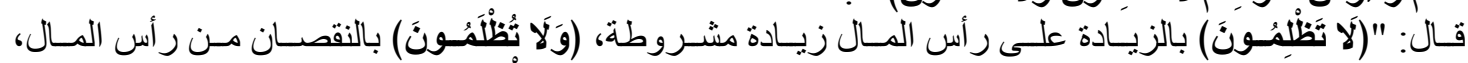

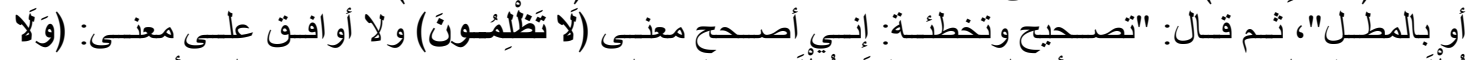

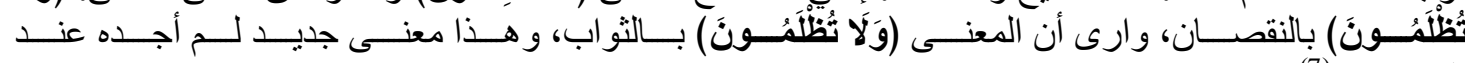

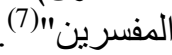

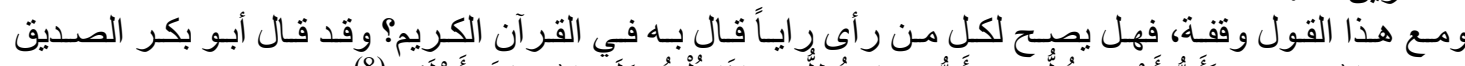

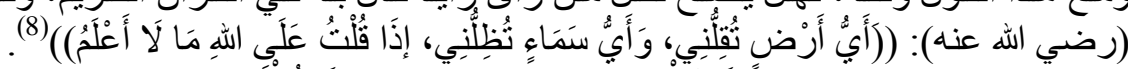

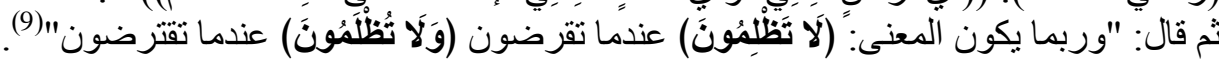

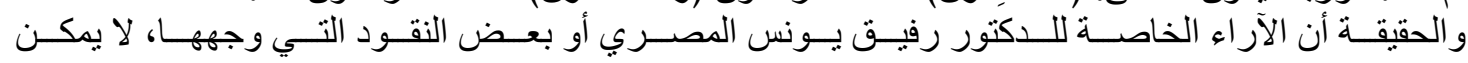

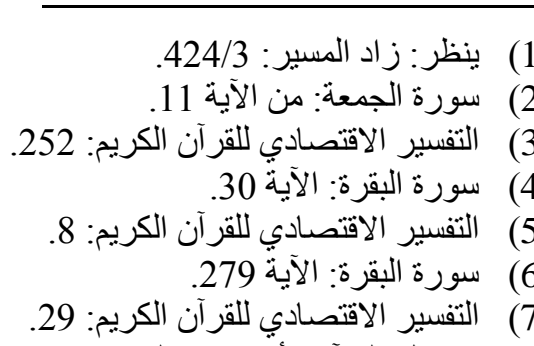

(8) فضائل القرآن، أبو عبيد القاسم بن سلام بن القبن عبد الله الهروي البغدادي (ت224هـ)، تحقيق مروان العطية، ومحسن

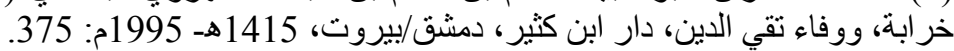
التفسير الاقتصنادي للقر آن الكريم: 30. 


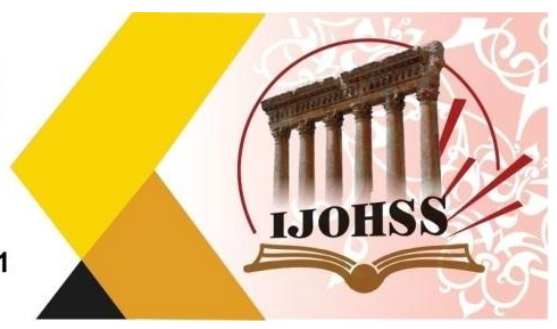

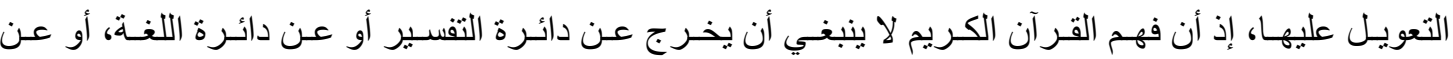
دائرة الحقائق العلمية، و إلا لقال كل من شاء ما شاء في كلاء فلام ربنا سبحانه ونعالى.

الخاتمة

الحمد لله حق حمده، و الصلاة و السلام على خبر خلقه سيدنا محمد و على آله وصحبه.

$$
\text { فأوجز أهم النتائج والمقترحات بما يأتي: }
$$

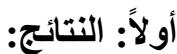

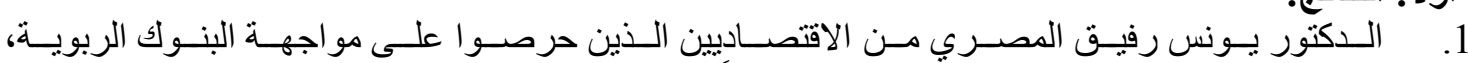

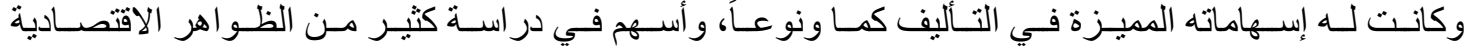

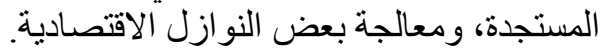

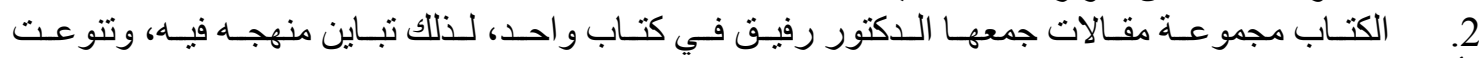
أساليبه.

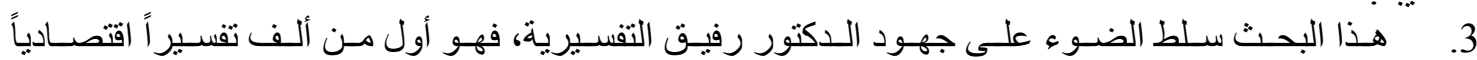

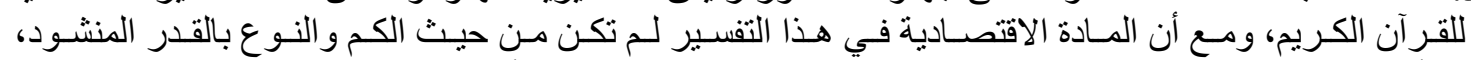

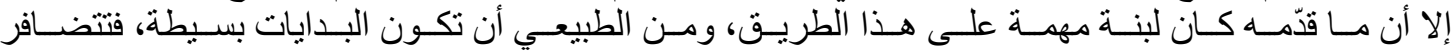

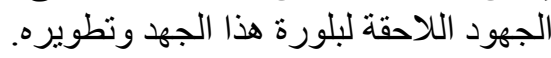

4. نجح الدكتور يونس في الربط بين تفسير القرآن الكريم وبين الجوانب الاقتصادية.

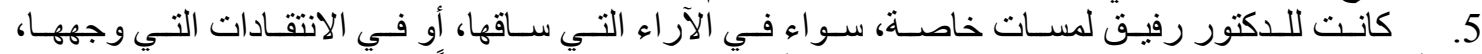

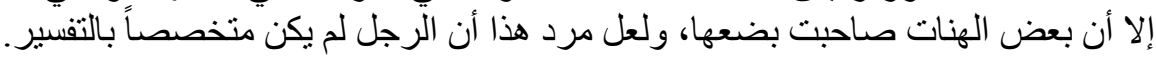

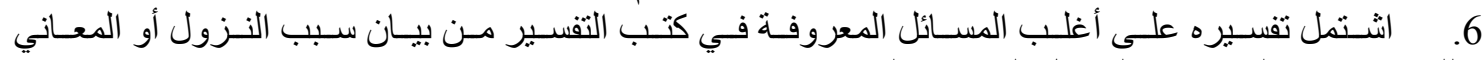
اللغوية، وذكر القراءات و المسائل النحوية والبلاغية و غير ها.

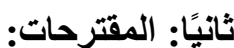

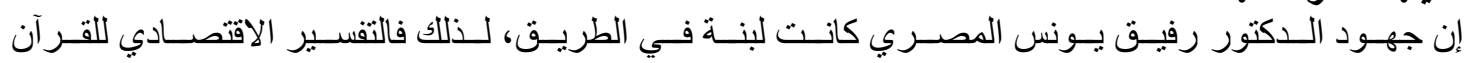

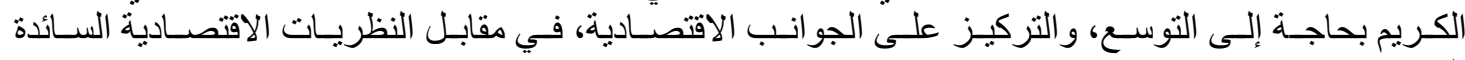
اليوم.

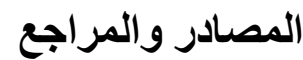

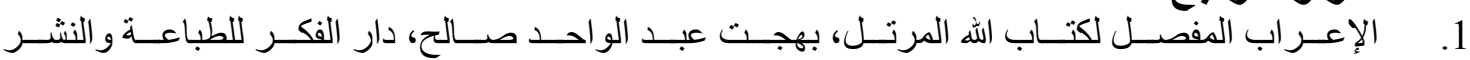

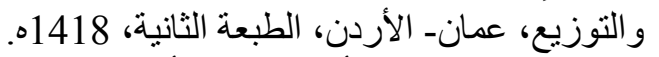

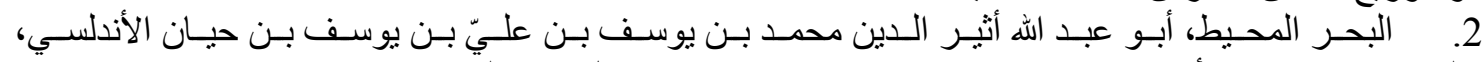

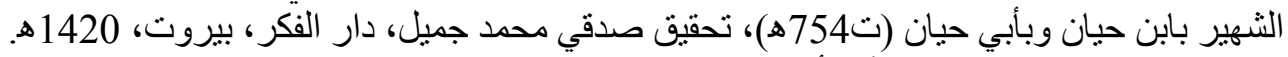

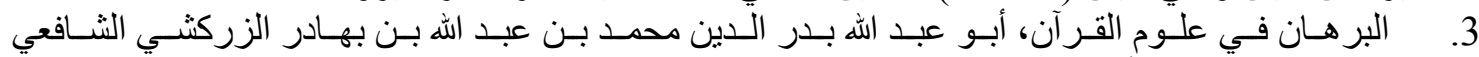

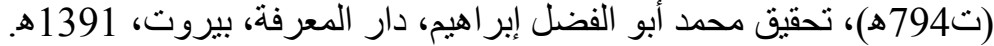

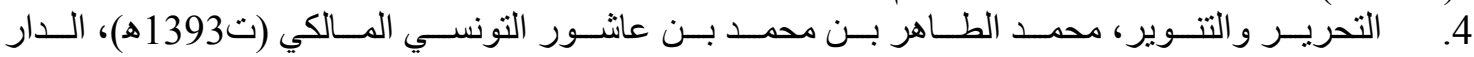
التونسية للنشر، تونس، والتس 1404 هـ- 1984م.

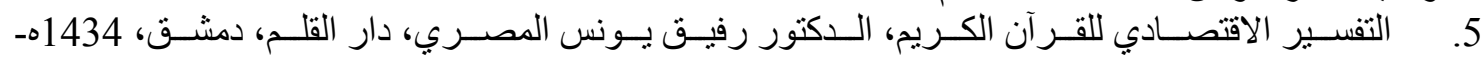
2013 


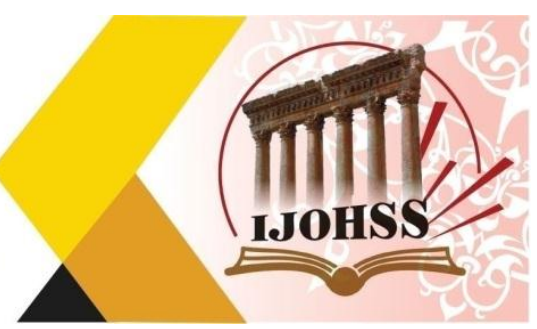

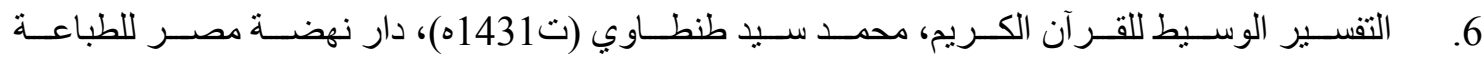
و النشر و التوزيع، القاهرة، 1998م.

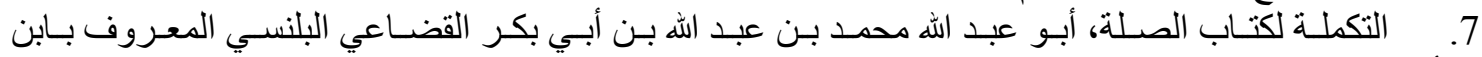

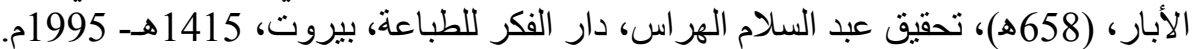

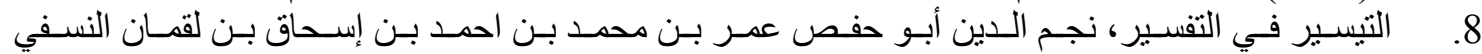

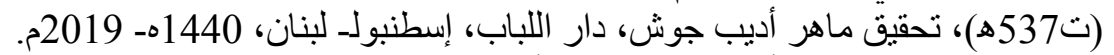

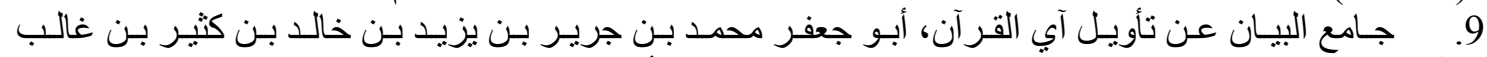

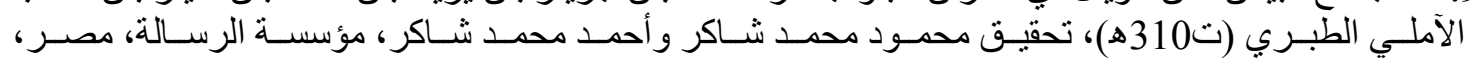
1420 هـ 2000 الطيري.

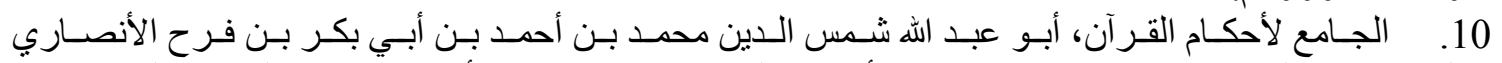

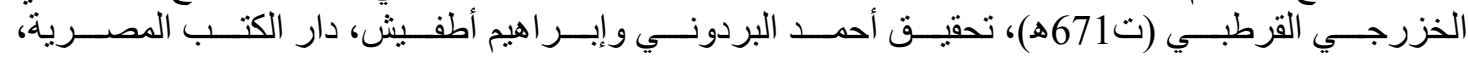

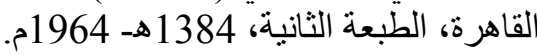

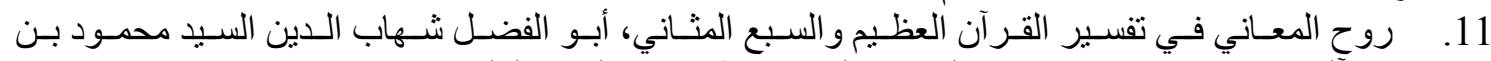

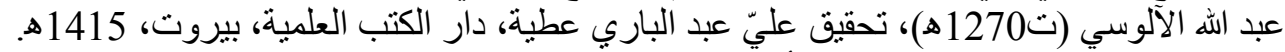

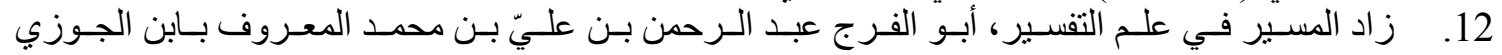

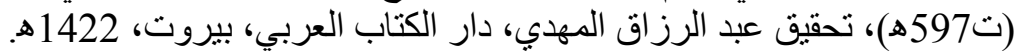

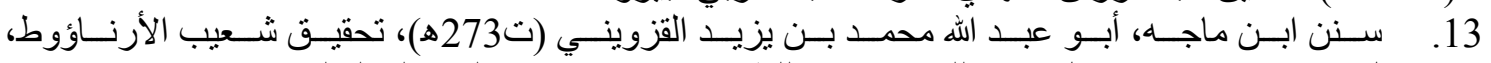

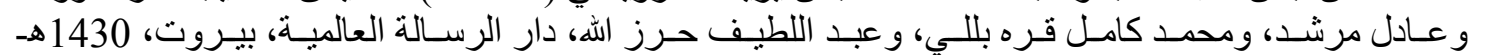
2009م.

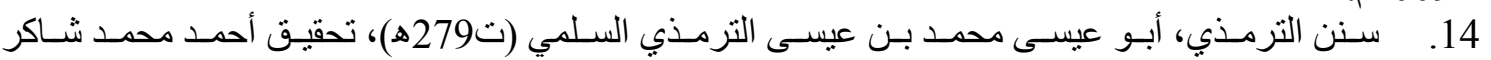

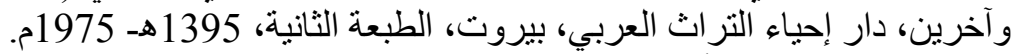

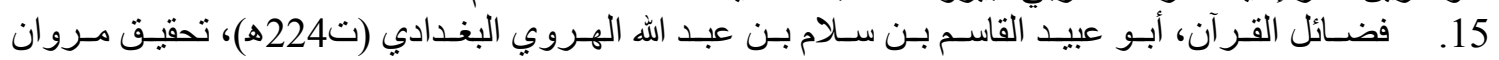

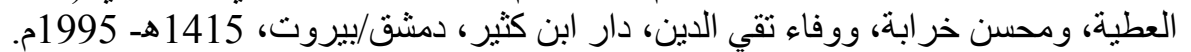

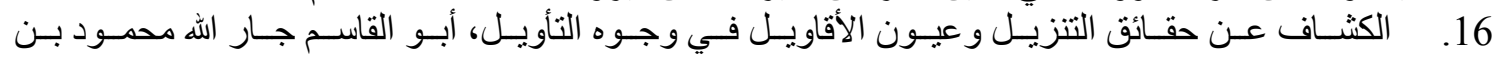

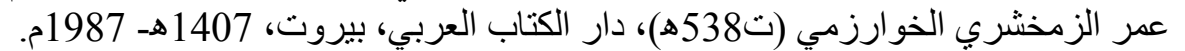

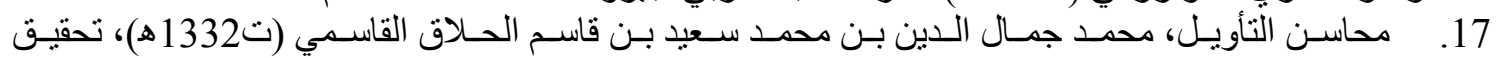

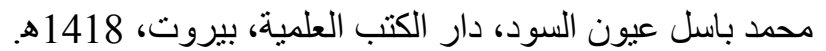

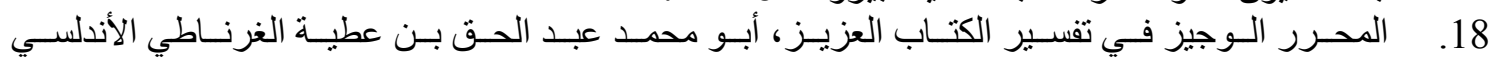

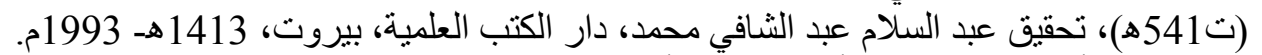

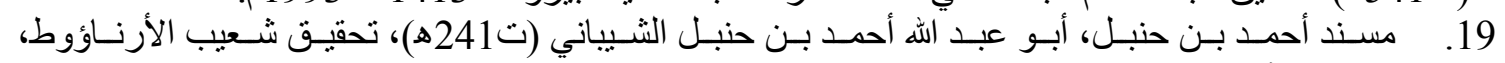

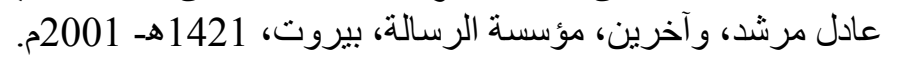

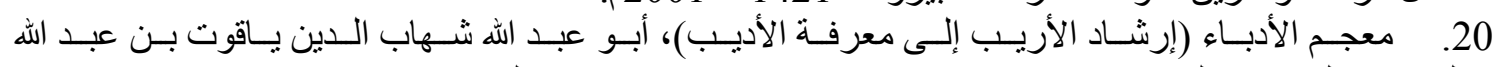

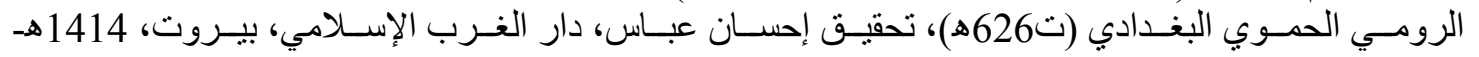

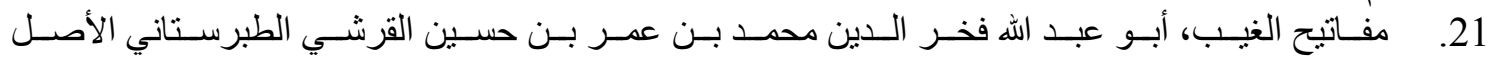

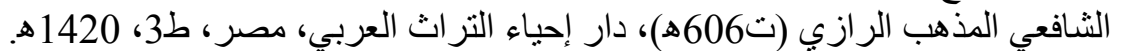

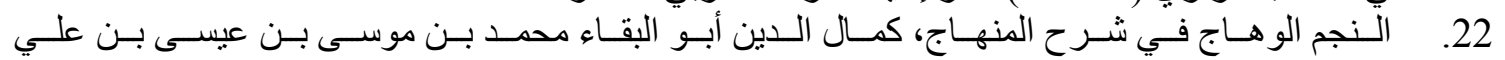

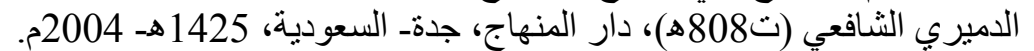

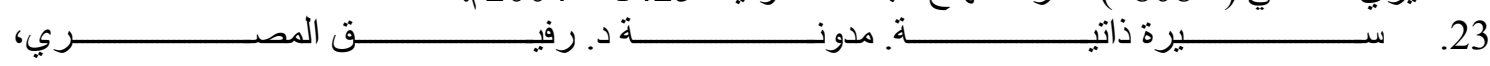
. https://drmasri.wordpress.com/author/drmasri/ 


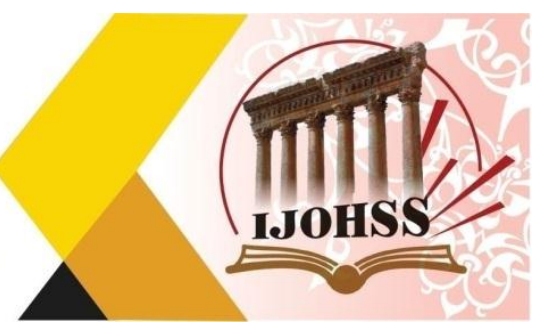

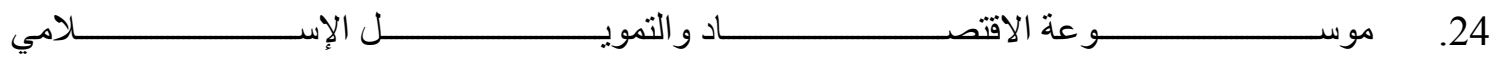

https://web.archive.org/web/20210721065421/https://iefpedia.com/arab/?p=2

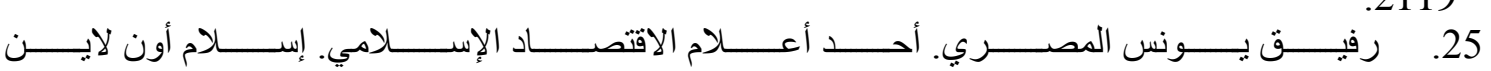
.https://web.archive.org/web/20210814222324/https 